\title{
Indoor Quality of Residential Homes and Schools of an Industrial Area in Asansol: Characterization, Bioaccessibility and Health Risk Assessment of Potentially Toxic Elements
}

\author{
M. Pal*, M. Gope**, A. Basu*, T. Laha*, R. E. Masto***, R. Labar****, T. K. Kundu****, R. R. Hoque*****, \\ P. S. Khillare****** and S. Balachandran*† \\ *Department of Environmental Studies, Siksha-Bhavana, Visva-Bharati, Santiniketan-731235, West Bengal, India \\ **Department of Chemistry, National Institute of Technology, Durgapur (NIT Durgapur), Durgapur-713209, \\ West Bengal, India \\ ***Environmental Management Division, CSIR-Central Institute of Mining and Fuel Research, Digwadih Campus, \\ CFRI, Dhanbad-826015, Jharkhand, India \\ ****Department of Physics, Siksha-Bhavana, Visva-Bharati, Santiniketan-731235, West Bengal, India \\ *****Department of Environmental Sciences, Tezpur University, Tezpur-784028, Assam, India \\ ******School of Environmental Sciences, Jawaharlal Nehru University, New Delhi-100 067, India \\ $\dagger$ Corresponding author: S. Balachandran; s.balachandran@visva-bharati.ac.in
}

Nat. Env. \& Poll. Tech.

Website: www.neptjournal.com

Received: 30-07-2020

Revised: $08-10-2020$

Accepted: 15-10-2020

Key Words:

Indoor dust

PTES

SBET

Health risk assessment

Monte Carlo analysis

\begin{abstract}
Bioaccessibility of eight potentially toxic elements (PTEs), their human exposure and health risk assessments were determined in the indoor dust of residence and schools from the Asansol Industrial area, India. The PTEs concentrations were maximum during the winter both at houses and schools. The average PTEs concentrations throughout the year in Asansol were 3.16, 120, 156, 41708, 2354, 61.3, 115 and $345 \mathrm{mg} \cdot \mathrm{kg}^{-1}$ for $\mathrm{Cd}, \mathrm{Cr}, \mathrm{Cu}, \mathrm{Fe}, \mathrm{Mn}, \mathrm{Ni}, \mathrm{Pb}$ and $\mathrm{Zn}$ respectively. X-ray powder diffraction indicated an abundance of quartz in the indoor dust. Principal component analysis (PCA) indicated multiple sources such as traffic, industries, and lithogenic sources for PTEs in indoor dust. Percentage of bioaccessibility was maximum for $\mathrm{Cd}$ (55.3\% throughout the year). Total PTEs concentration and a bioaccessible fraction of PTEs both were used for health risk assessment, and non-carcinogenic health risk was $<1$ for total PTEs and the bioaccessible fraction of PTEs. Health risk of total PTEs' $\left(\mathrm{HI}_{\text {total }}\right)$ for $\mathrm{Mn}$ was high for both children and adult (6.76E-01 and 1.3E-01, respectively). Monte Carlo simulation model indicated that all the cumulative probability of Hazard Quotient (HQ) for collectively eight metals was below 1.
\end{abstract}

\section{INTRODUCTION}

Indoor settled dust is an important environmental media, which needs serious attention due to increased levels of toxicants to which human are daily exposed. The primary sources of PTE's into the indoor environment are indoor activities and infiltration of the outdoor aerosols into indoors. Indoor activities like cooking, vacuum cleaning, smoking and resuspension of dust particles also contribute to indoor dust pollution (Ali et al. 2019). PTEs can enter into indoor through the suspended particles from the outdoor air (Rasmussen et al. 2018), high vehicular traffic (Rohra et al. 2018) and the dirt that adheres to footwear (Ali et al. 2019, Kelepertzis et al. 2019, Cheng et al. 2018). Various researches indicate that outdoor aerosols are a significant contributor to indoor pollutants, of which street dust can contribute to $20-95 \%$ to household dust (Rasmussen et al. 2001, Torres-Sanchez et al. 2017).
PTEs causes various health effects like decreased bone density, renal disorder, nervous system damage, disturb natural brain development etc. (Chen et al. 2015). Moreover, it interferes with the child's neural development which is highest during their growth period and is more risk-prone to PTEs (Muhamad-Darus et al. 2017). PTEs tend to accumulate into the tissue and results in biological magnification through time.

To accurately assess the ingested oral risk of PTEs exposure, it is essential to know the PTEs oral bioaccessibility. Although there are a lot of in vitro models developed to assess the bioavailability of PTEs among which SBET is a very simple process and also cost very low. Various studies were conducted to estimate the in-vitro bioaccessibility of PTEs in indoor settled dust (Bot et al. 2010, Turner 2011, Wang et al. 2016). However, in urban industrial areas like 
Asansol, India, which has various anthropogenic activities which release various PTEs (Gope et al. 2017); however, the oral bioaccessibility of various PTEs in indoor dust has not been investigated.

The overarching aim of this study was to analyse (i) the seasonal variation of PTE's level in indoor settled dust of houses and schools (ii) mineralogical study (iii) sources identification of PTEs (iv) oral bioaccessibility, (v) health risk assessment, and (vi) Monte Carlo simulation.

\section{MATERIAL AND METHODS}

\section{Study Area}

Asansol is a metropolitan city located in the western part of West Bengal, India, with medium industrial activities and a part of Chhotanagpur Plateau (Fig. 1). The population of this city was 5,64,491 as per the census of 2011 (Govt of India 2011). It is situated beside NH-2 'The Grant Trunk Road' one of the oldest and busiest roads in India. IISCO (Indian Iron and Steel Corporation), Eastern Coalfield, Burnpur Cement etc. are the primary industries located at Asansol industrial area. Very high traffic density was observed throughout 24 hrs. at Asansol, $>7000 \mathrm{~h}$ in peak hour and $>2000 \mathrm{~h}$ in the lean hour (Gope et al. 2017).

\section{Sample Collection}

Sites were selected randomly, and samples were collected from three residential areas, viz. Sarada Pally, Puranhat and Santinagar. Four houses from each residential area and four primary schools were selected for sample collection. Total 48 dust samples were collected throughout the study period, March 2014 to February 2015. A 0.5 square meter glass plate was kept on the top of the almirah and bunker. Settled dust was collected from the glass plate in a plastic zipper pack through a nylon brush and brought to the laboratory for analysis (Pitawala et al. 2013). Dust samples were collected in four months interval at schools and houses.

Ground floor was selected for sampling in case of houses, but in case of schools, the $1^{\text {st }}$ floor was used. Sarada Pally is very close to steel plant and $\mathrm{NH}$. The houses are east facing and well ventilated with 2 windows and two doors in the room where the plate was kept. In Puranhat area, houses are old; these are housing complex of steel industries. Houses are not well ventilated with the presence of one door plus one window at one side and one window on the other side. Santinagar is a very congested area and rooms are very small $(8 \times 8 \mathrm{ft})$. Only one door and one window are present on one side. All the schools are well ventilated with windows on three sides and door present on one side.

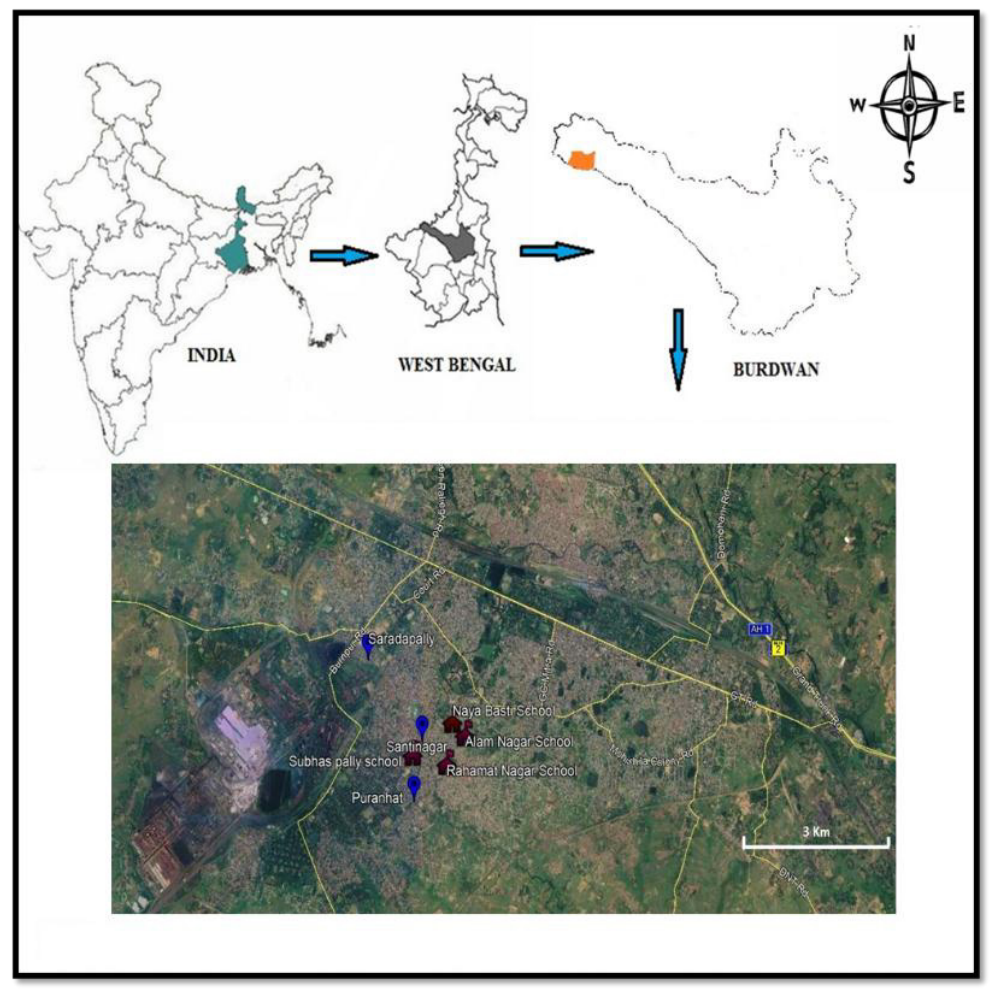

Fig. 1: The study area. 
Verandah is present in every school. Three schools (Naya Basti primary school, Allamnagar primary school and Rahamat Nagar primary school) are east facing and playground present in the east side just after verandah. Subhas Pally primary school is north facing, and they do not have any playground.

\section{Sample Preparation for Pseudo Total PTEs Concentration}

Dust samples of $0.2 \mathrm{~g}$ were weighed and transferred into a Teflon vessel. $\mathrm{HNO}_{3}$, $\mathrm{HF}$ and $\mathrm{HCl}$ were mixed with the dust samples in a ratio of 2:1:1 (v/v) and the mixture was digested for 35 minutes at $210^{\circ} \mathrm{C}$ temperature in a microwave digester (Jupiter-A, Sr. No. JP127A) and the digestion procedure was adopted from Hussain et al. (2015) with some modification as per our requirement. The digested solution was filtered using Whatman No. 42 filter paper and made up to $25 \mathrm{~mL}$ using $12 \mathrm{~N} \mathrm{HCl}$. PTEs concentration was measured by Inductively Coupled Plasma-Optical Emission Spectrometry (ICP-OES, iCAP 6300, Thermo Fisher Scientific, UK). Quality control and quality assurance are provided in our earlier paper (Gope et al. 2018).

\section{Sample Preparation for SBET}

During SBET extraction, $0.1 \mathrm{~g}$ dust was weighed out from each sample and transferred into a test tube, and $10 \mathrm{~mL} 0.4$ M Glycine ( $\mathrm{pH} 1.5$ ) was added to the sample, and the test tube was centrifuged at $30 \mathrm{rpm}$ at $37^{\circ} \mathrm{C}$ for one hour. After digestion, the aliquot was filtered through a $0.45 \mu \mathrm{m}$ cellulose acetate disk filter (Ruby et al. 1996, Oomen et al. 2002). Filtrates were stored at $4^{\circ} \mathrm{C}$ and analysed using Inductively Coupled Plasma-Optical Emission Spectrometry (ICP-OES) for detection of PTEs.

\section{Bioaccessibility}

Bioaccessibility was calculated using the following formula (Oomen et al. 2002).

Bioaccessibility percentage $(\%)=$ Metal concentration $\left(\frac{\mathrm{mg}}{\mathrm{kg}}\right)$ determined in gastric phase Total metal content $\left(\frac{\mathrm{mg}}{\mathrm{kg}}\right)$ in environmental media

$$
\times 100
$$

\section{XRD Analysis}

At room temperature, Rigaku Ultima IV with $\mathrm{CuK}_{\mathrm{a}}(\mathrm{k}=$ $1.514 \mathrm{~A}^{\circ}$, over the range, $2 \square 4-84^{\circ}$ ) was used to study X-ray Powder diffraction patterns of dust samples. To identify the phase, the obtained diffraction designs were studied using X'Pert High Score software and ICDD database (Labar \& Kundu 2018).

\section{Human Exposure Risk Assessment}

Ingestion, inhalation and dermal absorption are the three main exposure routes through which PTEs can enter into the body. The exposure risk assessment was calculated for children and adult. To assess the potential health risk, chronic daily intake (CDI) was calculated for each PTEs through individual exposure pathways.

$$
\begin{gathered}
C D I_{\text {ing }}=C \times \frac{R_{\text {ing }} \times F_{\text {exp }} \times T_{\text {exp }}}{A B W \times T_{\text {avrg }}} \times 10^{-6} \\
C D I_{\text {inh }}=C \times \frac{\mathrm{R}_{\text {inh }} \times F_{\text {exp }} \times T_{\text {exp }}}{P E F \times A B W \times T_{\text {avrg }}} \\
C D I_{\text {dermal }}=C \times \frac{\mathrm{SAF} \times A_{\text {skin }} \times D A F \times F_{\text {exp }} \times T_{\text {exp }}}{A B W \times T_{\text {avrg }}} \times 10^{-6}
\end{gathered}
$$

Where, CDI = Chronic Daily Intake (mg.kg ${ }^{-1} \cdot$ day $\left.^{-1}\right) ; \mathrm{C}$ $=$ Concentration of PTE; $\mathrm{R}_{\mathrm{ing}}=$ Ingestion rate $[200 \mathrm{mg}$ dust day $^{-1}$ for children (1-6 years), 100 mg.day ${ }^{-1}$ for adults]; $R_{\text {inh }}=$ Inhalation rate $\left(20 \mathrm{~m}^{3}\right.$.day ${ }^{-1}$ for adults, $7.6 \mathrm{~m}^{3}$.day ${ }^{-1}$ for child); $\mathrm{F}_{\text {exp }}=$ Exposure frequency [ 365 day.year $\left.{ }^{-1}\right] ; \mathrm{T}_{\exp }=$ Exposure duration [6 years for child and 24 years for adults]; $\mathrm{A}_{\text {skin }}$ $=$ Skin area [2800 $\mathrm{cm}^{2}$ for child and $5700 \mathrm{~cm}^{2}$ for adults]; $\mathrm{SAF}=$ Skin adherence factor $\left[0.2 \mathrm{mg} \cdot \mathrm{cm}^{-2} \cdot \mathrm{h}^{-1}\right.$ for child and $0.07 \mathrm{mg} . \mathrm{cm}^{-2} \cdot \mathrm{h}^{-1}$ for adults]; DAF $=$ Dermal absorption factor (unit less), [0.001 for both child and adults]; PEF = Particle Emission Factor $\left[1.36 \times 10^{9} \mathrm{~m}^{3} \cdot \mathrm{kg}^{-1}\right.$ for both cases]; $\mathrm{ABW}=$ Average Body Weight $(18 \mathrm{~kg}$ for child and $60 \mathrm{~kg}$ for adults); $\mathrm{T}_{\mathrm{avrg}}=$ Averaging Time (for non-carcinogens, $\left.\mathrm{T}_{\mathrm{avrg}}=\mathrm{T}_{\exp } \times 365\right)$ (Gope et al. 2018).

Hazard Quotient (HQ) was calculated for individual PTE in each exposure pathway. The calculated CDI values were subtracted with the corresponding reference dose (RfD) of PTEs. Reference doses were listed in Table 3.

$$
H Q=\sum \frac{C D I}{R f D}
$$

Hazard index (HI) was calculated for each PTE. HI is the summation of three HQ for each PTE.

$$
H I=\sum H Q
$$

\section{Statistical Analysis}

Principal Component Analysis (PCA), and Tukey test of PTEs were done by SPSS statistical software version 21 .

Monte Carlo simulation was performed by using Crystal Ball (v11.1.1.1.00).

\section{RESULTS AND DISCUSSION}

\section{Total PTEs Content}

The concentration of all PTEs in the indoor dust of houses 
and schools varied significantly by season (Fig. 2). Studied eight PTEs had maximum concentration $(\mathrm{Cd}, \mathrm{Cr}, \mathrm{Cu}, \mathrm{Fe}$, $\mathrm{Mn}, \mathrm{Ni}, \mathrm{Pb}$ and $\mathrm{Zn}$ ) during the winter followed by summer and monsoon (Fig. 2). In summer, for ventilation, windows and doors are kept open, leading to accumulation of dust in the indoor environment and due to windy (maximum $3.6 \mathrm{~km} / \mathrm{hr}$ ) and dry condition (maximum $48^{\circ} \mathrm{C}$ ). In monsoon due to heavy rain, pollutants could have washed-out from atmosphere leading to a low concentration of aerosols in the outdoor and ultimately leading to less PTEs concentration during monsoon (Kulshrestha et al. 2009). Low atmospheric temperature, low mixing height and temperature inversion during winter would have led to the movement of fine dust through the window and doorsill and get accumulated into the indoor environment from an outdoor source could be responsible for higher PTEs concentration in winter when compared to monsoon and summer (Khillare et al. 2004, Kulshrestha et al. 2009). A similar variation of PTEs concentration in street dust was also reported by Gope (2016) in Asansol.

A maximum Cd concentration of $4.94 \pm 1.6$ and $3.85 \pm$ $1.9 \mathrm{mg} \cdot \mathrm{kg}^{-1}$ was observed in houses and schools respectively during winter. The major source of $\mathrm{Cd}$ in indoor dust could be from other outdoor sources like coal combustion, petroleum combustion and fossil fuel burning (Li et al. 2016, Soleimani et al. 2018). The high concentration of $\mathrm{Cd}$ in indoor dust at Asansol is due to the influence of outdoor aerosols into the indoor environment, originating from industrial activities like ceramic industries, steel plant (Liang et al. 2017, Soleimani

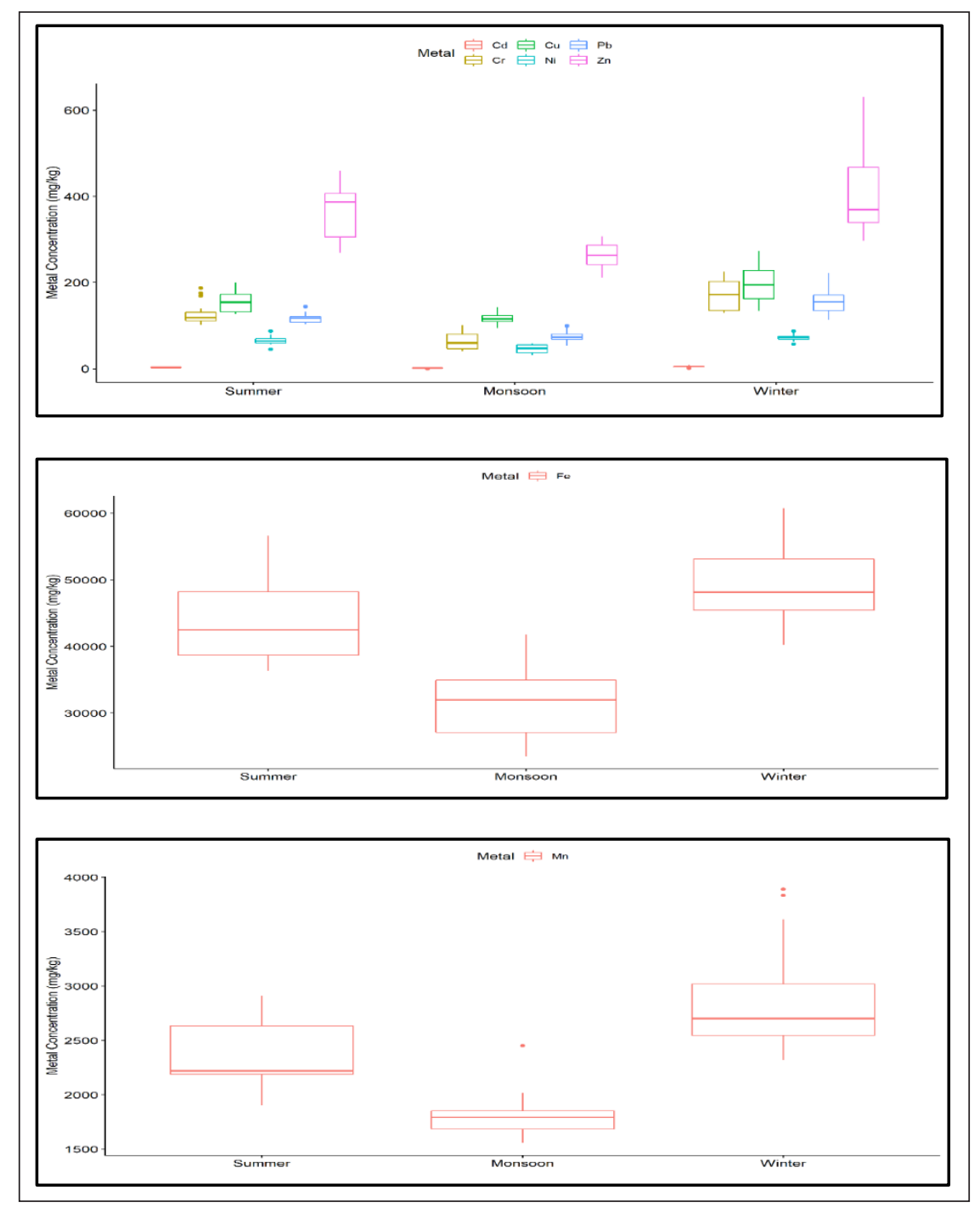

Fig. 2: Seasonal variation of total PTEs (Cd, $\mathrm{Cr}, \mathrm{Cu}, \mathrm{Fe}, \mathrm{Mn}, \mathrm{Ni}, \mathrm{Pb}$ and $\mathrm{Zn}$ ) concentration in settled indoor dust of Asansol. 
et al. 2018), cement industries (Shen et al. 2017, Hua et al. 2016), fossil fuel burning, engine oil, and tires wear (Novo et al. 2017, Gope et al. 2018).

During winter maximum average $\mathrm{Cr}$ concentration in Asansol was $169 \pm 33 \mathrm{mg} . \mathrm{kg}^{-1}$ while the maximum average concentration at schools was $135 \pm 2.5 \mathrm{mg} \cdot \mathrm{kg}^{-1}$. The high concentration of $\mathrm{Cr}$ in the indoor could be sourced to infiltration of outdoor aerosols into indoor which might be due to their release from the vehicles traffic (Muhamad-Darus et al. 2017, Soleimani et al. 2018), weathering of $\mathrm{Cr}-\mathrm{Ni}$ plated automobile parts, yellow road paint (Iwegbue et al. 2017) and some indoor sources of $\mathrm{Cr}$ are mosquito coil and incense stick burning (Lin \& Shen 2003, 2005), Cr coated household items (Iwegbue et al. 2017, Al-madanat et al. 2017, Muhamad-Darus et al. 2017).

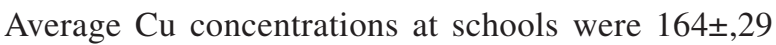
$6.0 \pm 116$ and $33 \pm 179 \mathrm{mg} \cdot \mathrm{kg}^{-1}$ during summer, monsoon and winter respectively. $\mathrm{Cu}$ concentration was highest $(196 \pm 42$ $\mathrm{mg} . \mathrm{kg}^{-1}$ ) during winter and was lowest during monsoon $\left(117 \pm 11 \mathrm{mg} \cdot \mathrm{kg}^{-1}\right)$. Uses of $\mathrm{Cu}$ based biocides in home gardens and $\mathrm{Cu}$ containing wood preservatives (copper arsenate, copper sulphate, etc.) are the sources of indoor $\mathrm{Cu}$ contamination (Iwegbue et al. 2017). Vehicular emission is a very common source of $\mathrm{Cu}$ (Muhamad-Darus et al. 2017, Al-madanat et al. 2017) as well as coal combustion (Gope et al. 2018) which could be transported from outdoor to indoor environment. Besides, vehicular emission, industries at Asansol use coal as a fuel and which could increase $\mathrm{Cu}$ concentration in outdoor as well as indoor.

The average $\mathrm{Fe}$ concentration was highest during the winter $\left(49538 \pm 6004 \mathrm{mg} \cdot \mathrm{kg}^{-1}\right)$ followed by summer $\left(44044 \pm 6045 \mathrm{mg} \cdot \mathrm{kg}^{-1}\right)$ and monsoon (31544 \pm $5697 \mathrm{mg} \cdot \mathrm{kg}^{-1}$ ), while maximum Fe concentration at schools was $53863 \pm 6656 \mathrm{mg} \cdot \mathrm{kg}^{-1}$ during winter followed by summer $\left(44523 \pm 4576 \mathrm{mg} \cdot \mathrm{kg}^{-1}\right)$ and monsoon (27782 \pm $\left.4066 \mathrm{mg} \cdot \mathrm{kg}^{-1}\right)$. Fe concentration is high in lateritic soil (Goldberg 1989, Emeh et al. 2019), and this Fe containing dust enter into houses from the playground, roadside dust, and different barren places. Steel industries and various ferroalloy industries are also major sources of Fe pollution, which could enter into indoor through outdoor aerosol. During monsoon, heavy rain decreases the dust levels leading to decreased Fe concentration in indoor dust.

The highest average Mn concentration was observed at houses during winter $\left(2881 \pm 499 \mathrm{mg} \cdot \mathrm{kg}^{-1}\right)$ at Asansol. Maximum average $\mathrm{Mn}$ concentration at schools was $3115 \pm 755 \mathrm{mg} \cdot \mathrm{kg}^{-1}$ during winter. Major sources of $\mathrm{Mn}$ in household dust could be the use of household washing agents, and outdoor sources for automobile emissions (Iwegbue et al. 2017). Mn is the main raw material used in steel plant and is the main source of Mn contamination in an outdoor environment (Gope et al. 2018), and Mn contaminated aerosol enter into indoor from the outdoor environment.

Average highest Ni concentration at Asansol was 72.6 $\pm 7.93 \mathrm{mg} \cdot \mathrm{kg}^{-1}$ during winter, while the highest average $\mathrm{Ni}$ concentration in schools was $65.5 \pm 7.6 \mathrm{mg} . \mathrm{kg}^{-1}$ during winter. Some of the major indoor sources of $\mathrm{Ni}$ in the indoor environment are mosquito coil and incense burning (Lin \& Shen 2005, Li et al. 2016). Ni is mainly released into the outdoor environment from vehicular emission, iron-steel plant, thermal power plant (mainly combustion of coal) (Muhamad-Darus et al. 2017, Li et al. 2016, Wan et al. 2016, Soleimani et al. 2018) which is entered into houses and schools through outdoor aerosol.

The average $\mathrm{Pb}$ concentrations were $117 \pm 10.9$, $75.4 \pm 13.5$ and $154 \pm 27.9 \mathrm{mg} . \mathrm{kg}^{-1}$ during summer, monsoon and winter respectively, while in schools, the maximum $\mathrm{Pb}$ concentration was $136 \pm 16 \mathrm{mg} \cdot \mathrm{kg}^{-1}$ during winter. The major indoor sources of $\mathrm{Pb}$ are $\mathrm{Pb}$-based paint, lead solder, lead pipes, cigarette smoke (Iwegbue et al. 2017). The sources of $\mathrm{Pb}$ in indoor could be traced the dust emitted from industries, which could penetrate the indoor environment like vehicular exhausts (Iwegbue et al. 2017, Nawazish et al. 2017), coal combustion (Pacyna et al. 2009, Sen et al. 016), fly ash from fly ash brick manufacturing plant (Gope et al. 2018), cement industries (Bermudez et al. 2010), etc.

The average $\mathrm{Zn}$ concentration was $363 \pm 58.8,263 \pm$ 30.1 and $410 \pm 94.7 \mathrm{mg} \cdot \mathrm{kg}^{-1}$ respectively during summer, monsoon and winter in Asansol. $\mathrm{Zn}$ concentration was higher during winter than summer and monsoon. Maximum $\mathrm{Zn}$ concentration in schools was $345 \pm 32 \mathrm{mg} . \mathrm{kg}^{-1}$ during winter. $\mathrm{Zn}$ can be sourced into indoor dust from rubber underlay, galvanized iron roofing, and carpets (Iwegbue et al. 2017). Depreciation of vulcanized rubber tires, decomposition of galvanized vehicular parts, and lubricating oils also release $\mathrm{Zn}$ in the outdoor environment which could be traced into the indoor environment by outdoor aerosols (MuhamadDarus et al. 2017, Sulaiman et al. 2017). Moreover, brass and bronze, dry cell batteries, paints, rubber, ceramic are responsible for $\mathrm{Zn}$ contamination in indoor dust (Gope et al. 2018).

Comparison of total PTEs concentration in indoor dust reported from other countries along with this study is presented in Table 1.

\section{Mineral Composition}

X-ray diffraction study was performed to identify the various minerals present in the indoor dust samples (Fig. 3a, 3b). Quartz and magnetite was the most abundant mineral present in the analysed indoor dust. The identified quartz minerals 
M. Pal et al.

Table 1: Comparison of Total PTEs concentrations $(\mathrm{mg} / \mathrm{kg}$ dry weight) in house dust of Asansol $(\mathrm{n}=48)$ with other studies.

\begin{tabular}{|c|c|c|c|c|c|c|c|c|c|c|c|}
\hline $\begin{array}{l}\text { S. } \\
\text { No }\end{array}$ & $\begin{array}{l}\text { Type of } \\
\text { Indoor dust }\end{array}$ & Location & $\mathrm{Cd}$ & $\mathrm{Cr}$ & $\mathrm{Cu}$ & $\mathrm{Fe}$ & $\mathrm{Mn}$ & $\mathrm{Ni}$ & $\mathrm{Pb}$ & $\mathrm{Zn}$ & References \\
\hline 2 & $\begin{array}{l}\text { Household } \\
\text { dust }\end{array}$ & Istanbul, Turkey & 0.80 & 55.0 & 156 & n.a & 136 & 263 & 28.0 & 832 & $\begin{array}{l}\text { Kurt-Karakus } \\
\text { (2012) }\end{array}$ \\
\hline 3 & Indoor dust & Canada & 6 & 117 & 279 & n.a & n.a & 102 & 210 & 833 & $\begin{array}{l}\text { Rasmussen et al. } \\
\text { (2013) }\end{array}$ \\
\hline 4 & Indoor dust & $\begin{array}{l}\text { Katmandu, } \\
\text { Nepal }\end{array}$ & 8.2 & 29.9 & & n.a & n.a & 23.9 & 40 & 76.2 & Shakya (2013) \\
\hline 5 & Indoor dust & $\begin{array}{l}\text { Pretoria, South } \\
\text { Africa }\end{array}$ & 1.47 & 109 & 186 & 11000 & n.a & 59.5 & 110 & 669 & $\begin{array}{l}\text { Kefeni and } \\
\text { Okonkwo (2013) }\end{array}$ \\
\hline 7 & Preschools & Malaysia & 0.23 & 11.9 & n.a & 4801 & & n.a & 253.5 & 144.9 & $\begin{array}{l}\text { Latif et al. } \\
\text { (2014) }\end{array}$ \\
\hline 8 & Indoor & Tokyo, Japan & 1.02 & 67.8 & 304 & 10000 & 226 & 59.6 & 57.9 & 920 & $\begin{array}{l}\text { Yoshinaga et al. } \\
\text { (2014) }\end{array}$ \\
\hline 9 & $\begin{array}{l}\text { Nursery } \\
\text { schools }\end{array}$ & Xi'an, China & n.a & 159.7 & 74.20 & n.a & 397.5 & 36.2 & 176.2 & 462.6 & Lu et al. (2014) \\
\hline 11 & $\begin{array}{l}\text { Primary } \\
\text { schools }\end{array}$ & $\begin{array}{l}\text { Sri Serdang, } \\
\text { Malaysia }\end{array}$ & 1.73 & n.a & 54.71 & n.a & n.a & n.a & 34.17 & n.a & $\begin{array}{l}\text { Praveena et al. } \\
\text { (2015) }\end{array}$ \\
\hline 14 & Indoor dust & $\begin{array}{l}\text { Huainan city, } \\
\text { China }\end{array}$ & n.a & 76.5 & 114.5 & n.a & n.a & 41.8 & 116.9 & 602.8 & Lin et al. (2016) \\
\hline 15 & Indoor dust & $\begin{array}{l}\text { Xi'an, Central } \\
\text { China }\end{array}$ & n.a & 94.6 & 100.7 & n.a & 452.9 & 157.5 & 148.4 & 621.1 & Wan et a. (2016) \\
\hline 16 & Indoor dust & $\begin{array}{l}\text { Hunan } \\
\text { Province, China }\end{array}$ & 2.15 & 130.1 & 34.3 & n.a & 445 & 119.3 & 72.07 & 250.2 & Cao et al. (2016) \\
\hline 17 & Indoor dust & Chengdu, China & 8.31 & 315 & 419 & n.a & 879 & 495 & 366 & 2630 & Li et al. (2016) \\
\hline 18 & Indoor dust & Tianjin, China & 2.98 & 127 & 171 & n.a & 604 & 68.9 & 181 & 1370 & Li et al. (2016) \\
\hline 19 & Indoor dust & $\begin{array}{l}\text { Delta State, } \\
\text { Nigeria }\end{array}$ & $\begin{array}{l}\text { BDL- } \\
21.2\end{array}$ & $\begin{array}{l}\text { BDL- } \\
117\end{array}$ & $\begin{array}{l}3.37- \\
2310\end{array}$ & $\begin{array}{l}219- \\
37,700\end{array}$ & $\begin{array}{l}4.25- \\
365\end{array}$ & $\begin{array}{l}\text { BDL- } \\
471\end{array}$ & $\begin{array}{l}\text { BDL- } \\
182\end{array}$ & $\begin{array}{l}6.18- \\
61,600\end{array}$ & $\begin{array}{l}\text { Iwegbue et al. } \\
\text { (2017) }\end{array}$ \\
\hline 20 & Indoor dust & Huelva (Spain) & 2 & 69 & 965 & 20000 & n.a & 55 & 152 & 882 & $\begin{array}{l}\text { Torres-Sánchez } \\
\text { et al. (2017) }\end{array}$ \\
\hline 21 & Indoor dust & $\begin{array}{l}\text { Al-Karak city, } \\
\text { Jordan }\end{array}$ & n.a & 72.5 & 90.5 & n.a & 38.8 & 90.5 & 51.39 & n.a & $\begin{array}{l}\text { Al-Madanat et } \\
\text { al. (2017) }\end{array}$ \\
\hline 22 & Indoor dust & $\begin{array}{l}\text { Cawangan } \\
\text { Pahang, } \\
\text { Malaysia }\end{array}$ & n.a & n.a & $\begin{array}{l}97.42- \\
193.7\end{array}$ & $\begin{array}{l}10809- \\
51312\end{array}$ & n.a & n.a & $\begin{array}{l}8.72- \\
27.36\end{array}$ & $\begin{array}{l}2879- \\
30776\end{array}$ & $\begin{array}{l}\text { Sulaiman et al. } \\
\text { (2017) }\end{array}$ \\
\hline 23 & Indoor dust & Chengdu, China & 2.37 & 82.7 & 190 & n.a & n.a & 52.6 & 123 & 675 & $\begin{array}{l}\text { Cheng et al. } \\
\text { (2018) }\end{array}$ \\
\hline 25 & Indoor dust & $\begin{array}{l}\text { Estarreja, } \\
\text { Portugal }\end{array}$ & 1.4 & 63 & 311 & n.a & 188 & 73 & 380 & 2090 & $\begin{array}{l}\text { Plumejeaud et al. } \\
\text { (2018) }\end{array}$ \\
\hline 26 & Indoor dust & Asansol & 3.16 & 120 & 156 & 41708 & 2354 & 61.3 & 115 & 345 & Present study \\
\hline
\end{tabular}

were preiswerkite, clintonite, fayalite with clay forming minerals such as calcite, gypsum, dolomite, microcline, muscovite, prasochrome, zincian. $\mathrm{Pb}$ containing mineral such as anglesite $\left(\mathrm{PbSO}_{4}\right)$ was observed which could be due to traffic and fly ash released from fossil fuel burning. Wulfenite $\left(\mathrm{PbMoO}_{4}\right)$, a secondary mineral, was detected in one sample, but the intensity was low. $\mathrm{ZnMoO}_{8}$ is a zinc-containing mineral found in the Asansol industrial area. Magnetite and hematite were detected in both the samples. Siderite $\left(\mathrm{FeCO}_{3}\right)$ and pyrite $\left(\mathrm{FeS}_{2}\right)$, iron-containing minerals were found in the indoor dust samples. Iron-containing minerals are introduced in the indoor dust due to fossil-fuel burning, traffic emissions, steel plant and other industries (Ram et al. 2014, Lu et al. 2007). Presence of clay forming mineral-like dolomite $\left[\mathrm{CaMg}\left(\mathrm{CO}_{3}\right)_{2}\right]$ could be due to cement industries present in the Asansol industrial area.

\section{Source Identification}

Principal component analysis (PCA): PCA was used to identify the PTEs sources in the indoor settled dust of Asansol 


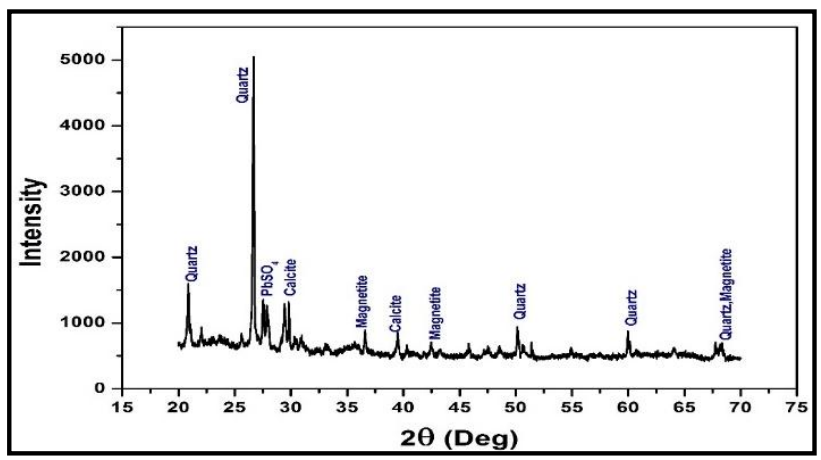

(a)

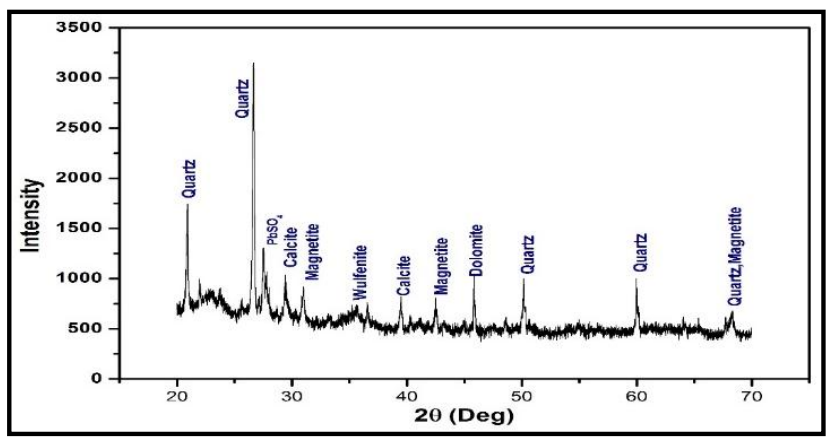

(b)

Fig. 3: XRD of dust samples ( $a$ and b) collected from Asansol.

industrial area (Table 2a). In this study, two components were extracted with $81.55 \%$ of the total variance. $\mathrm{Cd}, \mathrm{Cr}$, $\mathrm{Cu}, \mathrm{Ni}, \mathrm{Pb}$, and $\mathrm{Zn}$ occupied the same component with respective loading of $0.809,0.700,0.709,0.695,0.745$, 0.885 might be indicating traffic emission. Kelepertzis et al. (2019) supported the traffic source of $\mathrm{Pb}, \mathrm{Zn}$, and $\mathrm{Cu}$. Traffic source of $\mathrm{Cd}, \mathrm{Cr}$, and $\mathrm{Ni}$ was also supported by Dehghani et al. (2017). On the other hand, Fe and Mn were in PC2 component indicating the industrial source and lithogenic source of Fe and Mn. Lithogenic source of Fe and Mn also reported in a study in Athens (Kelepertzis et al. 2019) in a study in Athens, Greece, moreover Fe and Mn might also be released from steel industries (Gope et al. 2018).

Tukey analysis: Season wise significant difference of PTEs can be explained by Post-Hoc (Tukey) analysis (Table 2b). Tukey analysis showed that $\mathrm{Cd}, \mathrm{Cr}, \mathrm{Cu}, \mathrm{Mn}$, and $\mathrm{Pb}$ concentrations were significantly different during summer, monsoon, and winter at $95 \%$ significant level but $\mathrm{Fe}, \mathrm{Ni}$, and $\mathrm{Zn}$ concentration was not significantly different during
Table 2: a) Principal Component Analysis (PCA), and b) Tukey analysis results of studied PTEs $(\mathrm{Cd}, \mathrm{Cr}, \mathrm{Cu}, \mathrm{Fe}, \mathrm{Mn}, \mathrm{Ni}, \mathrm{Pb}$ and $\mathrm{Zn}$ ) in the deposited indoor dust of Asansol.

(a) Principal component analysis (PCA).

Rotated Component Matrix

\begin{tabular}{|lll|}
\hline PTEs & \multicolumn{2}{l|}{ Component } \\
\cline { 2 - 3 } & 1 & 2 \\
\hline $\mathrm{Cd}$ & .809 & .429 \\
$\mathrm{Cr}$ & .700 & .574 \\
$\mathrm{Cu}$ & .709 & .567 \\
$\mathrm{Fe}$ & .330 & .885 \\
$\mathrm{Mn}$ & .415 & .758 \\
$\mathrm{Ni}$ & .695 & .502 \\
$\mathrm{~Pb}$ & .745 & .516 \\
$\mathrm{Zn}$ & .885 & .255 \\
$\%$ of variance & 46.86 & 34.70 \\
$\mathrm{Cumulative} \%$ & 46.86 & 81.55 \\
\hline
\end{tabular}


(b) Tukey analysis.

\begin{tabular}{|c|c|c|c|c|c|}
\hline \multirow[t]{2}{*}{ PTEs } & \multirow[t]{2}{*}{ Season } & \multirow[t]{2}{*}{ Season } & \multirow[t]{2}{*}{ Significance } & \multicolumn{2}{|c|}{$95 \%$ confidence interval } \\
\hline & & & & Lower boundary & Upper boundary \\
\hline \multirow[t]{3}{*}{$\mathrm{Cd}$} & Summer & Monsoon & 0.001 & 0.59 & 2.48 \\
\hline & Summer & Winter & 0 & -2.85 & -0.96 \\
\hline & Monsoon & Winter & 0 & 4.38 & -2.49 \\
\hline \multirow[t]{3}{*}{$\mathrm{Cr}$} & Summer & Monsoon & 0 & 40.7 & 86.8 \\
\hline & Summer & Winter & 0 & -64.3 & -18.2 \\
\hline & Monsoon & Winter & 0 & -128 & -82.0 \\
\hline \multirow[t]{3}{*}{$\mathrm{Cu}$} & Summer & Monsoon & 0.001 & 14.4 & 63.3 \\
\hline & Summer & Winter & 0.001 & -65.1 & -16.1 \\
\hline & Monsoon & Winter & 0 & -104 & -54.9 \\
\hline \multirow[t]{3}{*}{$\mathrm{Fe}$} & Summer & Monsoon & 0 & 7430 & 17571 \\
\hline & Summer & Winter & 0.031 & -10564 & -423 \\
\hline & Monsoon & Winter & 0 & -23065 & -12923 \\
\hline \multirow[t]{3}{*}{$\mathrm{Mn}$} & Summer & Monsoon & 0 & 255 & 873 \\
\hline & Summer & Winter & 0.001 & -816 & -198 \\
\hline & Monsoon & Winter & 0 & -1381 & -762 \\
\hline \multirow[t]{3}{*}{$\mathrm{Ni}$} & Summer & Monsoon & 0 & 10.9 & 27.1 \\
\hline & Summer & Winter & 0.076 & -15.5 & 0.62 \\
\hline & Monsoon & Winter & 0 & -34.5 & -18.4 \\
\hline \multirow[t]{3}{*}{$\mathrm{Pb}$} & Summer & Monsoon & 0 & 25.0 & 57.6 \\
\hline & Summer & Winter & 0 & -53.8 & -21.3 \\
\hline & Monsoon & Winter & 0 & -95.1 & -62.6 \\
\hline \multirow[t]{3}{*}{$\mathrm{Zn}$} & Summer & Monsoon & 0 & 43.0 & 157 \\
\hline & Summer & Winter & 0.132 & -103 & 10.8 \\
\hline & Monsoon & Winter & 0 & -204 & -89.4 \\
\hline
\end{tabular}

* The mean difference is significant at the 0.05 level.

summer and winter. $\mathrm{Fe}, \mathrm{Ni}$, and $\mathrm{Zn}$ concentration were not significantly different during summer and winter, which might be due to the influences of some local sources of these PTEs. Cement industries at Asansol industrial area situated at the north-east region of the area and as in summer the wind at that area blow from the North-East direction, the $\mathrm{Zn}$ concentration in that area is not significantly different during winter with summer. During summer and winter, the dispersion of pollutants is different, which could be responsible for $\mathrm{Fe}, \mathrm{Zn}$, and $\mathrm{Ni}$ concentration not significant during these two seasons.

\section{Bioaccessibility}

Seasonal variation of PTEs bioaccessibility in indoor settled dust was observed and represented as the percentage of bioaccessibility (Fig. 4a). Cd and Zn bioaccessibility was higher during the summer, followed by winter. Bioaccessibility of $\mathrm{Cr}, \mathrm{Cu}, \mathrm{Ni}$, and $\mathrm{Pb}$ was higher during the winter followed by the monsoon. Fe and Mn bioaccessibility was maximum during monsoon followed by summer. Seasonal variation of bioaccessibility was observed in the indoor settled dust at Asansol industrial area might be due to different soil parameters, and this theory was supported in a study reported from China (Wang et al. 2016). The bioaccessible fraction of Cd was higher when compared to other PTEs, and the bioaccessible fraction of Fe was lower in the present study. The main controlling factors of bioaccessibility of PTEs are speciation of PTEs, $\mathrm{pH}$, presence of organic matter and mineral composition of matter (Roussel et al. 2010, Hu et al. 2012, Pelfrene et al. 2012, 2013). Mineralogy is one of the important controlling factors of bioaccessibility (Ettler et al. 2019). PTEs might occur as exchangeable form, reducible form, oxidizable form and residual form, which plays an important role in Bioaccessibility. SBET estimate the amount of PTEs that is dissolved from ingested dust in the gastric juice and available for transport through the intestinal membrane 


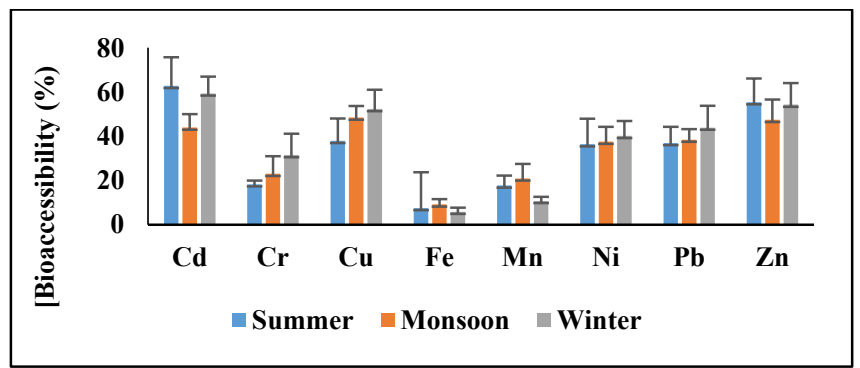

(a)

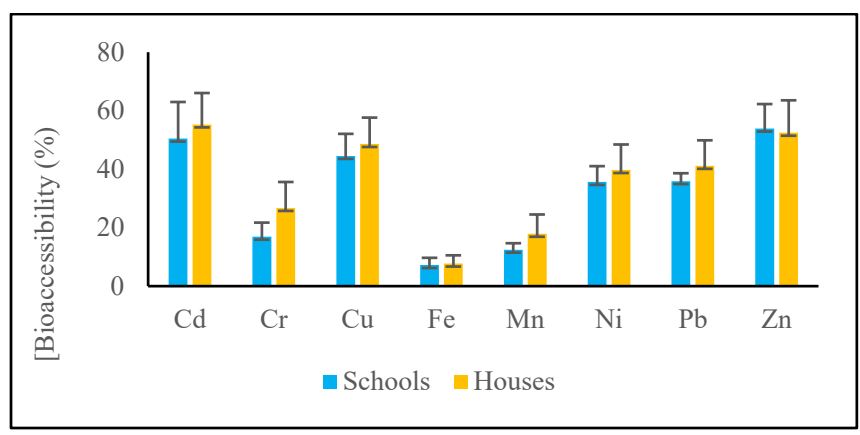

(b)

Fig. 4: (a) Bioaccessible fraction (\%) of PTEs in indoor dust of Asansol (b) comparison of bioaccessible fraction (\%) between schools and houses.

(Cao et al. 2009, Hu et al. 2012, Wang et al. 2016). Low $\mathrm{pH}$ of gastric juice is responsible for the bioaccessibility of PTEs. The decreasing order of bioaccessible fraction was $\mathrm{Cd}>\mathrm{Zn}>\mathrm{Cu}>\mathrm{Pb}>\mathrm{Ni}>\mathrm{Cr}>\mathrm{Mn}>\mathrm{Fe}$ during summer and winter, but during monsoon the order was $\mathrm{Cu}>\mathrm{Zn}>\mathrm{Cd}>$ $\mathrm{Pb}>\mathrm{Ni}>\mathrm{Cr}>\mathrm{Mn}>\mathrm{Fe}$.

In this study, the bioaccessibility fraction between schools and houses (Fig. 4b) was compared. Only Zn bioaccessibility was higher in schools than houses, while bioaccessibility of other 7 PTEs was higher in house dust. Mainly outdoor aerosol particulates vehicular exhausts are responsible for high Zn bioaccessibility in schools' dust.

\section{Human Health Risk Assessment}

The health risk of PTEs was calculated for children and adult in the indoor settled dust samples of Asansol industrial area (Table 3). Ingestion, inhalation, and dermal contacts are the three main pathways and were considered for health risk assessment. Hazard Quotient (HQ) and Hazard Index (HI) were separately calculated for each PTE. In this study, total PTEs concentration and SBET-extracted PTEs concentration were used separately for health risk assessment. During use of total PTEs ( $\mathrm{Cd}, \mathrm{Cr}, \mathrm{Cu}, \mathrm{Mn}, \mathrm{Ni}, \mathrm{Pb}$ and $\mathrm{Zn}$ ) concentration for health risk assessment, ingestion was the main exposure route both in child and adults followed by dermal contact ( $\mathrm{Li}$ et al. 2013, Wang et al. 2016) but in case of Fe, maximum risk observed for dermal contact. During use of SBET-extracted PTEs concentration for health risk assessment, the result was similar like total PTEs concentration. Here, ingestion was the main exposure followed by dermal contact for all observed PTEs except Fe. Decreasing order of non-carcinogenic health risk for total PTEs concentration was $\mathrm{Mn}>\mathrm{Fe}>\mathrm{Cr}>\mathrm{Pb}>$ $\mathrm{Cd}>\mathrm{Cu}>\mathrm{Ni}>\mathrm{Zn}$ and $\mathrm{Fe}>\mathrm{Mn}>\mathrm{Cr}>\mathrm{Pb}>\mathrm{Zn}>\mathrm{Cd}>\mathrm{Cu}>$ $\mathrm{Ni}>\mathrm{Zn}$ in children and adults respectively, whereas risk for SBET-extracted PTEs concentration was $\mathrm{Fe}>\mathrm{Mn}>\mathrm{Cr}>\mathrm{Pb}$ $>\mathrm{Cu}>\mathrm{Cd}>\mathrm{Ni}>\mathrm{Zn}$ and $\mathrm{Fe}>\mathrm{Mn}>\mathrm{Cr}>\mathrm{Pb}>\mathrm{Cd}>\mathrm{Cu}>\mathrm{Ni}$ $>\mathrm{Zn}$ in children and adults respectively. In all cases, health risk due to $\mathrm{Zn}$ was lower when compared to other observed PTEs. The health risk assessment of the actual concentration of ingested and absorbed PTEs measured by SBET is more reliable and accurate (Oomen et al. 2002, Wang et al. 2016). Calculated health risk both for total PTEs concentration and SBET-extracted concentration of PTEs were $<1$, indicating non-carcinogenic health risk was observed in the indoor settled dust of residence and schools at Asansol industrial area. Calculated health risk also indicated that children were more vulnerable group than adult (Gu et al. 2018, Gope et al. 2018). The $\mathrm{HI}$ values of $\mathrm{Fe}, \mathrm{Mn}$ and $\mathrm{Cr}$ were close to 1 , which indicates that these PTEs can cause health risk in future. 
Monte Carlo simulation was performed only for ingested PTEs, and the distribution of the parameters are given in Table 4a and 4b. Cumulative hazard index of PTEs ingestion was calculated for the Monte Carlo simulation. From the sim- ulation, it is clear that $95 \%$ of the values of HQ (collectively for eight metals) was below 1 . We can see that the cumulative HI was maximum during winter and was minimum during monsoon for both child and adult. From the cumulative

Table 3: Human Health risk assessment using total metal and SBET-extracted concentration of studied PTEs $(\mathrm{Cd}, \mathrm{Cr}, \mathrm{Cu}, \mathrm{Mn}, \mathrm{Ni}, \mathrm{Pb}$ and $\mathrm{Zn})$ in the settled indoor dust of Asansol.

\begin{tabular}{|c|c|c|c|c|c|c|c|c|}
\hline \multirow[t]{2}{*}{ PTEs } & \multirow[t]{2}{*}{ Type of Exposure } & \multirow[t]{2}{*}{ RfD } & \multicolumn{2}{|l|}{ Summer } & \multicolumn{2}{|l|}{ Monsoon } & \multicolumn{2}{|l|}{ Winter } \\
\hline & & & Child & Adult & Child & Adult & Child & Adult \\
\hline \multirow[t]{6}{*}{$\mathrm{Cd}$} & Ingestion & $1.00 \mathrm{E}-03$ & $2.89 \mathrm{E}-03$ & $1.73 \mathrm{E}-03$ & $1.43 \mathrm{E}-03$ & $8.57 \mathrm{E}-04$ & $4.70 \mathrm{E}-03$ & $2.82 \mathrm{E}-03$ \\
\hline & Ingestion $_{\text {bioaccessible }}$ & $1.00 \mathrm{E}-03$ & $1.80 \mathrm{E}-03$ & $1.08 \mathrm{E}-03$ & $6.50 \mathrm{E}-04$ & $3.90 \mathrm{E}-04$ & $2.74 \mathrm{E}-03$ & $1.64 \mathrm{E}-03$ \\
\hline & Inhalation & $5.70 \mathrm{E}-06$ & $1.86 \mathrm{E}-05$ & 4.47E-05 & $9.21 \mathrm{E}-06$ & $2.21 \mathrm{E}-05$ & $3.03 \mathrm{E}-05$ & $7.28 \mathrm{E}-05$ \\
\hline & Dermal & $1.00 \mathrm{E}-05$ & 8.09E-04 & $6.91 \mathrm{E}-04$ & $4.00 \mathrm{E}-04$ & $3.42 \mathrm{E}-04$ & $1.32 \mathrm{E}-03$ & $1.13 \mathrm{E}-03$ \\
\hline & $\mathrm{HI}_{\text {total metal }}$ & & $3.72 \mathrm{E}-03$ & $2.47 \mathrm{E}-03$ & $1.84 \mathrm{E}-03$ & $1.22 \mathrm{E}-03$ & $6.05 \mathrm{E}-03$ & $4.02 \mathrm{E}-03$ \\
\hline & $\mathrm{HI}_{\text {bioaccessible }}$ & & $2.63 \mathrm{E}-03$ & $1.81 \mathrm{E}-03$ & $1.06 \mathrm{E}-03$ & $7.54 \mathrm{E}-04$ & $4.08 \mathrm{E}-03$ & $2.84 \mathrm{E}-03$ \\
\hline \multirow[t]{6}{*}{$\mathrm{Cr}$} & Ingestion & $3.00 \mathrm{E}-03$ & 4.06E-02 & $2.43 \mathrm{E}-02$ & $2.03 \mathrm{E}-02$ & $1.22 \mathrm{E}-02$ & $5.37 \mathrm{E}-02$ & $3.22 \mathrm{E}-02$ \\
\hline & Ingestion $_{\text {bioaccessible }}$ & $3.00 \mathrm{E}-03$ & 7.39E-03 & $4.43 \mathrm{E}-03$ & 4.63E-03 & $2.78 \mathrm{E}-03$ & $1.75 \mathrm{E}-02$ & $1.05 \mathrm{E}-02$ \\
\hline & Inhalation & $2.80 \mathrm{E}-05$ & $1.60 \mathrm{E}-04$ & $3.84 \mathrm{E}-04$ & $8.01 \mathrm{E}-05$ & $1.92 \mathrm{E}-04$ & $2.11 \mathrm{E}-04$ & $5.07 \mathrm{E}-04$ \\
\hline & Dermal & $7.50 \mathrm{E}-05$ & $4.55 \mathrm{E}-03$ & $3.89 \mathrm{E}-03$ & $2.28 \mathrm{E}-03$ & $1.95 \mathrm{E}-03$ & $6.01 \mathrm{E}-03$ & $5.14 \mathrm{E}-03$ \\
\hline & $\mathrm{HI}_{\text {total metal }}$ & & $4.53 \mathrm{E}-02$ & $2.86 \mathrm{E}-02$ & $2.27 \mathrm{E}-02$ & $1.43 \mathrm{E}-02$ & $5.99 \mathrm{E}-02$ & $3.79 \mathrm{E}-02$ \\
\hline & $\mathrm{HI}_{\text {bioaccessible }}$ & & $1.21 \mathrm{E}-02$ & $8.70 \mathrm{E}-03$ & $6.98 \mathrm{E}-03$ & $4.92 \mathrm{E}-03$ & $2.37 \mathrm{E}-02$ & $1.61 \mathrm{E}-02$ \\
\hline \multirow[t]{6}{*}{$\mathrm{Cu}$} & Ingestion & 4.00E-02 & $3.70 \mathrm{E}-03$ & $2.22 \mathrm{E}-03$ & $2.78 \mathrm{E}-03$ & $1.67 \mathrm{E}-03$ & 4.67E-03 & $2.80 \mathrm{E}-03$ \\
\hline & Ingestion $_{\text {bioaccessible }}$ & $4.00 \mathrm{E}-02$ & $1.39 \mathrm{E}-03$ & $8.32 \mathrm{E}-04$ & $1.34 \mathrm{E}-03$ & $8.06 \mathrm{E}-04$ & $2.44 \mathrm{E}-03$ & $1.47 \mathrm{E}-03$ \\
\hline & Inhalation & $4.02 \mathrm{E}-02$ & $1.35 \mathrm{E}-07$ & $3.25 \mathrm{E}-07$ & $1.02 \mathrm{E}-07$ & $2.44 \mathrm{E}-07$ & $1.71 \mathrm{E}-07$ & 4.10E-07 \\
\hline & Dermal & $1.20 \mathrm{E}-02$ & $3.45 \mathrm{E}-05$ & $2.95 \mathrm{E}-05$ & $2.59 \mathrm{E}-05$ & $2.22 \mathrm{E}-05$ & $4.36 \mathrm{E}-05$ & 3.72E-05 \\
\hline & $\mathrm{HI}_{\text {total metal }}$ & & $3.74 \mathrm{E}-03$ & $2.25 \mathrm{E}-03$ & $2.80 \mathrm{E}-03$ & $1.69 \mathrm{E}-03$ & $4.71 \mathrm{E}-03$ & $2.84 \mathrm{E}-03$ \\
\hline & $\mathrm{HI}_{\text {bioaccessible }}$ & & $1.42 \mathrm{E}-03$ & $8.62 \mathrm{E}-04$ & $1.37 \mathrm{E}-03$ & $8.28 \mathrm{E}-04$ & $2.49 \mathrm{E}-03$ & $1.50 \mathrm{E}-03$ \\
\hline \multirow[t]{6}{*}{$\mathrm{Fe}$} & Ingestion & 8.40 & 4.99E-03 & $3.00 \mathrm{E}-03$ & $3.58 \mathrm{E}-03$ & $2.15 \mathrm{E}-03$ & $5.62 \mathrm{E}-03$ & 3.37E-03 \\
\hline & Ingestion $_{\text {bioaccessible }}$ & 8.40 & $3.82 \mathrm{E}-04$ & $2.29 \mathrm{E}-04$ & $3.33 \mathrm{E}-04$ & $2.00 \mathrm{E}-04$ & $3.28 \mathrm{E}-04$ & $1.97 \mathrm{E}-04$ \\
\hline & Inhalation & 7.0E-02 & $2.20 \mathrm{E}-05$ & $5.29 \mathrm{E}-05$ & $1.58 \mathrm{E}-05$ & $3.79 \mathrm{E}-05$ & $2.48 \mathrm{E}-05$ & $5.95 \mathrm{E}-05$ \\
\hline & Dermal & $2.2 \mathrm{E}-03$ & 5.34E-02 & $4.56 \mathrm{E}-02$ & $3.82 \mathrm{E}-02$ & $3.27 \mathrm{E}-02$ & $6.00 \mathrm{E}-02$ & $5.13 \mathrm{E}-02$ \\
\hline & $\mathrm{HI}_{\text {total metal }}$ & & $5.84 \mathrm{E}-02$ & 4.87E-02 & $4.18 \mathrm{E}-02$ & $3.49 \mathrm{E}-02$ & $6.57 \mathrm{E}-02$ & $5.48 \mathrm{E}-02$ \\
\hline & $\mathrm{HI}_{\text {bioaccessible }}$ & & $5.38 \mathrm{E}-02$ & $4.59 \mathrm{E}-02$ & $3.86 \mathrm{E}-02$ & $3.29 \mathrm{E}-02$ & $6.04 \mathrm{E}-02$ & $5.16 \mathrm{E}-02$ \\
\hline \multirow[t]{6}{*}{$\mathrm{Mn}$} & Ingestion & 4.60E-02 & 4.91E-02 & $2.95 \mathrm{E}-02$ & $3.75 \mathrm{E}-02$ & $2.25 \mathrm{E}-02$ & $5.96 \mathrm{E}-02$ & $3.58 \mathrm{E}-02$ \\
\hline & Ingestion $_{\text {bioaccessible }}$ & 4.60E-02 & $8.69 \mathrm{E}-03$ & $5.21 \mathrm{E}-03$ & $7.80 \mathrm{E}-03$ & $4.68 \mathrm{E}-03$ & $6.44 \mathrm{E}-03$ & $3.87 \mathrm{E}-03$ \\
\hline & Inhalation & $1.43 \mathrm{E}-05$ & $5.81 \mathrm{E}-03$ & $1.39 \mathrm{E}-02$ & 4.43E-03 & $1.06 \mathrm{E}-02$ & $7.05 \mathrm{E}-03$ & $1.69 \mathrm{E}-02$ \\
\hline & Dermal & $1.84 \mathrm{E}-03$ & $3.44 \mathrm{E}-03$ & $2.94 \mathrm{E}-03$ & $2.62 \mathrm{E}-03$ & $2.24 \mathrm{E}-03$ & 4.17E-03 & $3.57 \mathrm{E}-03$ \\
\hline & $\mathrm{HI}_{\text {total metal }}$ & & $5.84 \mathrm{E}-02$ & 4.64E-02 & $4.45 \mathrm{E}-02$ & $3.53 \mathrm{E}-02$ & 7.09E-02 & $5.63 \mathrm{E}-02$ \\
\hline & $\mathrm{HI}_{\text {bioaccessible }}$ & & $1.79 \mathrm{E}-02$ & $2.21 \mathrm{E}-02$ & $1.49 \mathrm{E}-02$ & $1.76 \mathrm{E}-02$ & $1.77 \mathrm{E}-02$ & $2.44 \mathrm{E}-02$ \\
\hline \multirow[t]{6}{*}{$\mathrm{Ni}$} & Ingestion & $2.00 \mathrm{E}-02$ & $3.10 \mathrm{E}-03$ & $1.86 \mathrm{E}-03$ & $2.20 \mathrm{E}-03$ & $1.32 \mathrm{E}-03$ & $3.46 \mathrm{E}-03$ & $2.07 \mathrm{E}-03$ \\
\hline & Ingestion $_{\text {bioaccessible }}$ & $2.00 \mathrm{E}-02$ & $1.16 \mathrm{E}-03$ & $6.79 \mathrm{E}-04$ & $8.27 \mathrm{E}-04$ & $4.96 \mathrm{E}-04$ & $1.40 \mathrm{E}-03$ & $8.39 \mathrm{E}-04$ \\
\hline & Inhalation & $2.06 \mathrm{E}-02$ & $1.11 \mathrm{E}-07$ & $2.66 \mathrm{E}-07$ & 7.84E-08 & $1.88 \mathrm{E}-07$ & $1.23 \mathrm{E}-07$ & $2.96 \mathrm{E}-07$ \\
\hline & Dermal & $5.40 \mathrm{E}-03$ & $3.22 \mathrm{E}-05$ & $2.75 \mathrm{E}-05$ & $2.28 \mathrm{E}-05$ & $1.95 \mathrm{E}-05$ & $3.58 \mathrm{E}-05$ & $3.06 \mathrm{E}-05$ \\
\hline & $\mathrm{HI}_{\text {total metal }}$ & & $3.13 \mathrm{E}-03$ & $1.89 \mathrm{E}-03$ & $2.22 \mathrm{E}-03$ & $1.34 \mathrm{E}-03$ & $3.49 \mathrm{E}-03$ & $2.10 \mathrm{E}-03$ \\
\hline & $\mathrm{HI}_{\text {bioaccessible }}$ & & $1.16 \mathrm{E}-03$ & 7.07E-04 & $8.50 \mathrm{E}-04$ & $5.16 \mathrm{E}-04$ & $1.44 \mathrm{E}-03$ & $8.70 \mathrm{E}-04$ \\
\hline
\end{tabular}




\begin{tabular}{|c|c|c|c|c|c|c|c|c|}
\hline \multirow[t]{2}{*}{ PTEs } & \multirow[t]{2}{*}{ Type of Exposure } & \multirow[t]{2}{*}{ RfD } & \multicolumn{2}{|l|}{ Summer } & \multicolumn{2}{|l|}{ Monsoon } & \multicolumn{2}{|l|}{ Winter } \\
\hline & & & Child & Adult & Child & Adult & Child & Adult \\
\hline \multirow[t]{6}{*}{$\mathrm{Pb}$} & Ingestion & $3.50 \mathrm{E}-03$ & $3.17 \mathrm{E}-02$ & $1.90 \mathrm{E}-02$ & $2.05 \mathrm{E}-02$ & $1.23 \mathrm{E}-02$ & 4.20E-02 & $2.52 \mathrm{E}-02$ \\
\hline & Ingestion $_{\text {bioaccessible }}$ & $3.50 \mathrm{E}-03$ & $1.17 \mathrm{E}-02$ & $7.01 \mathrm{E}-03$ & $7.95 \mathrm{E}-03$ & 4.77E-03 & $1.86 \mathrm{E}-02$ & $1.12 \mathrm{E}-02$ \\
\hline & Inhalation & $3.52 \mathrm{E}-03$ & $1.16 \mathrm{E}-06$ & $2.79 \mathrm{E}-06$ & $7.50 \mathrm{E}-07$ & $1.80 \mathrm{E}-06$ & $1.53 \mathrm{E}-06$ & $3.68 \mathrm{E}-06$ \\
\hline & Dermal & $5.25 \mathrm{E}-04$ & $5.93 \mathrm{E}-04$ & $5.07 \mathrm{E}-04$ & $3.83 \mathrm{E}-04$ & $3.27 \mathrm{E}-04$ & $7.83 \mathrm{E}-04$ & $6.70 \mathrm{E}-04$ \\
\hline & $\mathrm{HI}_{\text {total metal }}$ & & $3.23 \mathrm{E}-02$ & $1.96 \mathrm{E}-02$ & $2.09 \mathrm{E}-02$ & $1.26 \mathrm{E}-02$ & $4.27 \mathrm{E}-02$ & $2.58 \mathrm{E}-02$ \\
\hline & $\mathrm{HI}_{\text {bioaccessible }}$ & & $1.23 \mathrm{E}-02$ & $7.52 \mathrm{E}-03$ & $8.33 \mathrm{E}-03$ & $5.10 \mathrm{E}-03$ & $1.94 \mathrm{E}-02$ & $1.18 \mathrm{E}-02$ \\
\hline \multirow[t]{6}{*}{$\mathrm{Zn}$} & Ingestion & $3.00 \mathrm{E}-01$ & $1.15 \mathrm{E}-03$ & $6.92 \mathrm{E}-04$ & $8.36 \mathrm{E}-04$ & 5.01E-04 & $1.30 \mathrm{E}-03$ & $7.80 \mathrm{E}-04$ \\
\hline & Ingestion $_{\text {bioaccessible }}$ & $3.00 \mathrm{E}-01$ & $6.41 \mathrm{E}-04$ & $3.85 \mathrm{E}-04$ & $3.96 \mathrm{E}-04$ & $2.38 \mathrm{E}-04$ & 7.13E-04 & $4.28 \mathrm{E}-04$ \\
\hline & Inhalation & $3.00 \mathrm{E}-01$ & 4.24E-08 & $1.02 \mathrm{E}-07$ & $3.07 \mathrm{E}-08$ & 7.37E-08 & $4.78 \mathrm{E}-08$ & $1.15 \mathrm{E}-07$ \\
\hline & Dermal & $6.00 \mathrm{E}-02$ & $1.62 \mathrm{E}-05$ & $1.38 \mathrm{E}-05$ & $1.17 \mathrm{E}-05$ & $1.00 \mathrm{E}-05$ & $1.82 \mathrm{E}-05$ & $1.56 \mathrm{E}-05$ \\
\hline & $\mathrm{HI}_{\text {total metal }}$ & & $1.17 \mathrm{E}-03$ & $7.06 \mathrm{E}-04$ & $8.47 \mathrm{E}-04$ & $5.11 \mathrm{E}-04$ & $1.32 \mathrm{E}-03$ & $7.96 \mathrm{E}-04$ \\
\hline & $\mathrm{HI}_{\text {bioaccessible }}$ & & $6.57 \mathrm{E}-04$ & $3.99 \mathrm{E}-04$ & $4.08 \mathrm{E}-04$ & $2.48 \mathrm{E}-04$ & $7.31 \mathrm{E}-04$ & 4.43E-04 \\
\hline
\end{tabular}

Ingestion + Inhalation + Dermal $=\mathrm{HI}_{\text {total metal }}$

Ingestion $_{\text {bioaccessible }}+$ Inhalation + Dermal $=\mathrm{HI}_{\text {bioaccessible }}$

Table 4: Distribution of parameter for Monte Carlo simulation: (a) Parameters for different population group (b) distribution for PTEs.

(a) Parameters for the different population groups.

\begin{tabular}{|c|c|c|c|c|c|c|}
\hline Parameters & Symbols & Units & Distribution & Adult & Child & References \\
\hline Metal Concentration & $\mathrm{C}$ & & Log-normal & \multicolumn{2}{|c|}{ Changes according to seasons and metals } & Present Study \\
\hline \multirow[t]{2}{*}{ Ingestion rate } & IR & mg/day & Triangular & $25(0.1-50)$ & $\mathrm{X}$ & LaGoy (1987) \\
\hline & & & Log-normal & $\mathrm{X}$ & $24( \pm 4)$ & Stanek et al. (2001) \\
\hline Exposure Frequency & $\mathrm{EF}$ & Days/year & Triangular & $345(180-365)$ & $345(180-365)$ & Smith (1994) \\
\hline Exposure duration & $\mathrm{ED}$ & Years & Point & 24 & 6 & USEPA1991, USEPA (2011) \\
\hline \multirow[t]{2}{*}{ Body weight } & BW & $\mathrm{Kg}$ & Log-Normal & $58.7( \pm 12)$ & $\mathrm{X}$ & Yang et al. (2005) \\
\hline & & & Normal & $\mathrm{X}$ & $16.5( \pm 2.4)$ & ICMR (2009) \\
\hline Reference doses & RfD & $\mu \mathrm{g} / \mathrm{kg} / \mathrm{day}$ & Point & \multicolumn{2}{|c|}{ Changes according to metals } & USEPA (2011) \\
\hline
\end{tabular}

(b) Distribution for PTEs

\begin{tabular}{|llll|}
\hline Metal & Summer $(\mathrm{mg} / \mathrm{kg})$ & Monsoon $(\mathrm{mg} / \mathrm{kg})$ & Winter $(\mathrm{mg} / \mathrm{kg})$ \\
\hline $\mathrm{Cd}$ & $0.95( \pm 2.28)$ & $0.94( \pm 6.47)$ & $8,598.70( \pm 1.00)$ \\
$\mathrm{Cr}$ & $19.94( \pm 2.57)$ & $19.39( \pm 2.46)$ & $166.01( \pm 1.22)$ \\
$\mathrm{Cu}$ & $153.86( \pm 1.16)$ & $152.04( \pm 1.08)$ & $191.76( \pm 1.24)$ \\
$\mathrm{Fe}$ & $43,665.29( \pm 1.14)$ & $31,071.17( \pm 1.20)$ & $49,201.84( \pm 1.13)$ \\
$\mathrm{Mn}$ & $734.14( \pm 1.49)$ & $1,798.71( \pm 1.11)$ & $2,843.43( \pm 1.18)$ \\
$\mathrm{Ni}$ & $64.40( \pm 1.17)$ & $34,201.06( \pm 1.00)$ & $72.18( \pm 1.12)$ \\
$\mathrm{Pb}$ & $116.21( \pm 1.10)$ & $46.32( \pm 1.32)$ & $151.91( \pm 1.19)$ \\
$\mathrm{Zn}$ & $269,731.99( \pm 1.00)$ & $123,786.26( \pm 1.00)$ & $400.18( \pm 1.25)$ \\
\hline
\end{tabular}

*Values are given in geometric mean and standard deviation.

probabilistic simulation, it can be concluded that children are more susceptible than an adult during all three seasons. During the three seasons, the cumulative HQ of 8 metals indicated that risk was persistently higher for children than adult (Fig. 5a and b). Calculated cumulative hazard index of all 8 PTEs are given in Table 5 were the distributions were considered as point distribution. It is found out that baseline case falls within 1. Predicted probability density functions of non-carcinogenic risk for summer, monsoon, and winter for adult and child are given in Fig. 6.

\section{CONCLUSION}

PTEs concentration in most of the cases is high in the 
Table 5: HI value due to ingestion of different PTEs through Monte Carlo simulation.

\begin{tabular}{|c|c|c|c|c|c|c|c|c|}
\hline \multirow[t]{2}{*}{ PTEs } & \multirow[t]{2}{*}{ Type of Exposure } & \multirow[t]{2}{*}{ RfD } & \multicolumn{2}{|l|}{ Summer } & \multicolumn{2}{|l|}{ Monsoon } & \multicolumn{2}{|l|}{ Winter } \\
\hline & & & Child & Adult & Child & Adult & Child & Adult \\
\hline $\mathrm{Cd}$ & Ingestion $_{\text {bioaccessible }}$ & $1.00 \mathrm{E}-03$ & $1.80 \mathrm{E}-03$ & $1.08 \mathrm{E}-03$ & $6.50 \mathrm{E}-04$ & $3.90 \mathrm{E}-04$ & $2.74 \mathrm{E}-03$ & $1.64 \mathrm{E}-03$ \\
\hline $\mathrm{Cr}$ & Ingestion $_{\text {bioaccessible }}$ & $3.00 \mathrm{E}-03$ & 7.39E-03 & $4.43 \mathrm{E}-03$ & 4.63E-03 & $2.78 \mathrm{E}-03$ & $1.75 \mathrm{E}-02$ & $1.05 \mathrm{E}-02$ \\
\hline $\mathrm{Cu}$ & Ingestion $_{\text {bioaccessible }}$ & $4.00 \mathrm{E}-02$ & $1.39 \mathrm{E}-03$ & 8.32E-04 & $1.34 \mathrm{E}-03$ & 8.06E-04 & $2.44 \mathrm{E}-03$ & $1.47 \mathrm{E}-03$ \\
\hline $\mathrm{Fe}$ & Ingestion $_{\text {bioaccessible }}$ & $8.40 \mathrm{E}+00$ & $3.82 \mathrm{E}-04$ & $2.29 \mathrm{E}-04$ & 3.33E-04 & $2.00 \mathrm{E}-04$ & $3.28 \mathrm{E}-04$ & $1.97 \mathrm{E}-04$ \\
\hline $\mathrm{Mn}$ & Ingestion $_{\text {bioaccessible }}$ & $4.60 \mathrm{E}-02$ & 8.69E-03 & $5.21 \mathrm{E}-03$ & $7.80 \mathrm{E}-03$ & $4.68 \mathrm{E}-03$ & $6.44 \mathrm{E}-03$ & $3.87 \mathrm{E}-03$ \\
\hline $\mathrm{Ni}$ & Ingestion $_{\text {bioaccessible }}$ & $2.00 \mathrm{E}-02$ & $1.16 \mathrm{E}-03$ & $6.79 \mathrm{E}-04$ & $8.27 \mathrm{E}-04$ & 4.96E-04 & $1.40 \mathrm{E}-03$ & 8.39E-04 \\
\hline $\mathrm{Pb}$ & Ingestion $_{\text {bioaccessible }}$ & $3.50 \mathrm{E}-03$ & $1.17 \mathrm{E}-02$ & 7.01E-03 & $7.95 \mathrm{E}-03$ & 4.77E-03 & $1.86 \mathrm{E}-02$ & $1.12 \mathrm{E}-02$ \\
\hline $\mathrm{Zn}$ & Ingestion $_{\text {bioaccessible }}$ & $3.00 \mathrm{E}-01$ & $6.41 \mathrm{E}-04$ & $3.85 \mathrm{E}-04$ & $3.96 \mathrm{E}-04$ & $2.38 \mathrm{E}-04$ & 7.13E-04 & $4.28 \mathrm{E}-04$ \\
\hline \multicolumn{3}{|c|}{ Cumulative HQ (HI) } & $3.32 \mathrm{E}-02$ & $1.99 \mathrm{E}-02$ & $2.39 \mathrm{E}-02$ & $1.44 \mathrm{E}-02$ & $5.02 \mathrm{E}-02$ & $3.01 \mathrm{E}-02$ \\
\hline
\end{tabular}

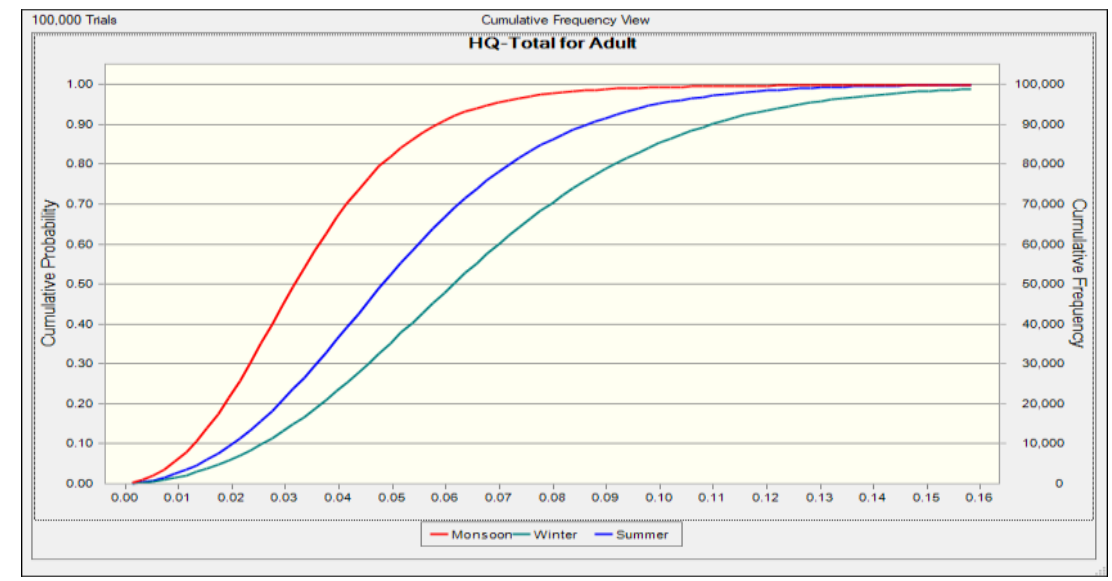

(a)

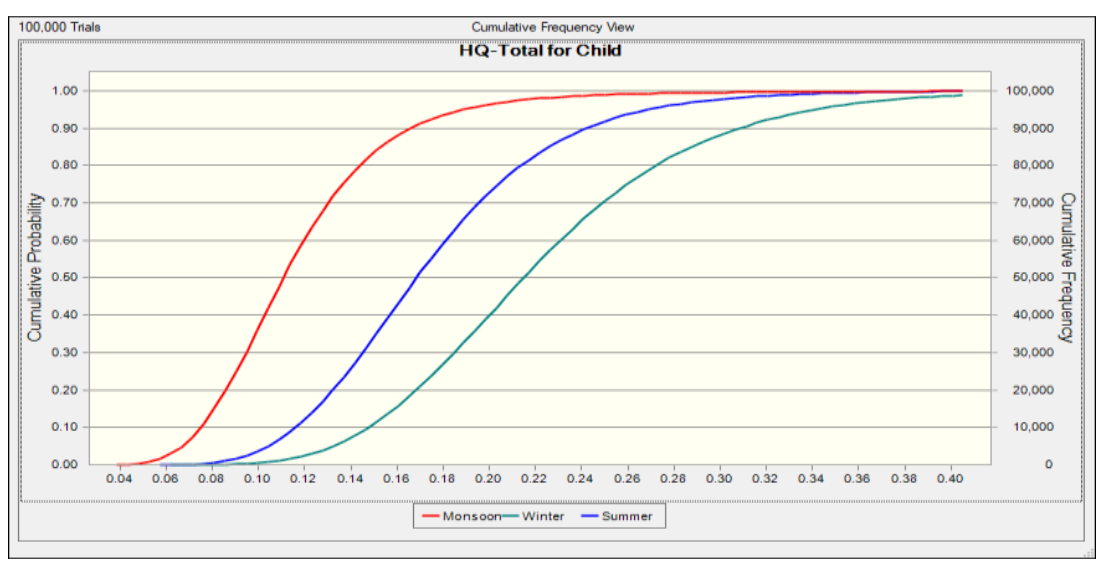

(b)

Fig. 5: Cumulative probability of hazard quotient (HQ) for (a) adult and (b) child during summer, monsoon and winter for bioaccessible metal content through Monte Carlo simulation. 


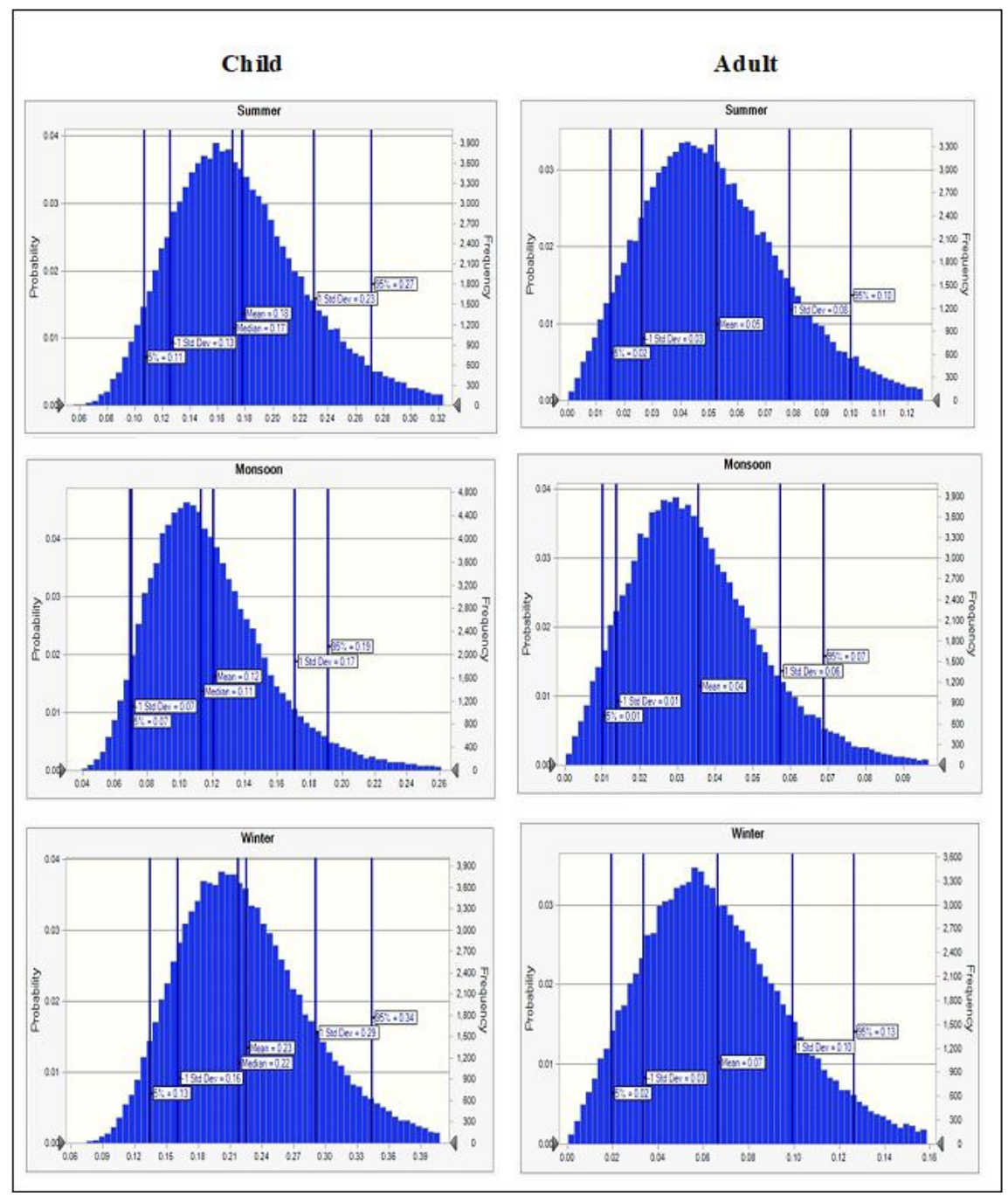

Fig. 6: Predicted probability density functions of non-carcinogenic risk for bioaccessible metal content in summer, monsoon, and winter for adult and child through Monte Carlo simulation.

house dust than school dust, which is highly influenced by the outdoor environment. During summer and winter, $\mathrm{Fe}$ and $\mathrm{Mn}$ concentrations were higher at schools. At schools, $\mathrm{Cu}$ concentration was higher during summer and $\mathrm{Cr}$ concentration during monsoon. It was observed that the major sources of PTE's in the indoor environment of schools and houses are from the outdoor environment, particularly from industries and vehicular exhaust. High Cd enrichment was noted at all four sampling sites of the Asansol industrial area. PCA indicated industrial emission, lithogenic and traffic-related materials as major sources. The health risk was $<1$ for total concentration and SBET-extracted PTEs concentration. Risk assessment with the average values for PTEs concentration indicated that $\mathrm{Cr}, \mathrm{Cu}, \mathrm{Fe}$ and $\mathrm{Pb}$ could cause health risk in future. Monte Carlo simulation depicted that chances of children getting affected by the PTEs are prominently higher than adults. Harmful effects of PTEs in different seasonal conditions vary differently, and the study concluded that in summer, monsoon, and winter scenario, monsoon, in general, is relatively less risky. Further studies are required encompassing a broader spectrum of the season and different social categories for a comprehensive understanding of risks associated with the PTEs. Studies enquiring further into identifying the particular sources, PTEs emission rate, chemical speciation and mobility of PTEs in indoor dust is required.

\section{ACKNOWLEDGEMENT}

The first author received fund from UGC Non-NET 
Fellowship through Visva-Bharati, Santiniketan, India during the work period. CSIR-Central Institute of Mining and Fuel Research (Digwadih Campus), Dhanbad (India) and Department of Environmental Sciences, Tezpur University, Assam are greatly acknowledged for their instrumental support during this work.

\section{REFERENCES}

Ali, M. U., Liu, G., Yousaf, B., Ullah, H., Irshad, S., Ahmed, R., Hussain, M. and Rashid, A. 2019. Evaluation of floor-wise pollution status and deposition behaviour of potentially toxic elements and nanoparticles in air conditioner dust during urbanistic development. Journal of Hazardous Materials, 365: 186-195.

Al-Madanat, O., Jiries, A., Batarseh, M. and Al-Nasir, F. 2017. Indoor and outdoor pollution with heavy metals in Al-Karak City, Jordan. J. Int. Environmental Application and Science, 12: 131-139.

Bermudez, G. M., Moreno, M., Invernizzi, R., Plá, R. and Pignata, M. L. 2010. Heavy metal pollution in topsoils near a cement plant: the role of organic matter and distance to the source to predict total and $\mathrm{HCl}-$ extracted heavy metal concentrations. Chemosphere, 78: 375-381.

Bot, B., Gilles, E., Durand, S. and Glorennec, P. 2010. Bioaccessible and quasi-total metals in soil and indoor dust. European Journal of Mineralogy, 22: 651-657.

Cao, S., Duan, X., Zhao, X., Chen, Y., Wang, B., Sun, C., Zheng, B. and Wei, F. 2016. Health risks of children's cumulative and aggregative exposure to metals and metalloids in a typical urban environment in China. Chemosphere, 147: 404-411.

Cao, X., Wahbi, A., Ma, L., Li, B. and Yang, Y. 2009. Immobilization of Zn, $\mathrm{Cu}$, and $\mathrm{Pb}$ in contaminated soils using phosphate rock and phosphoric acid. Journal of Hazardous Materials, 164: 555-564.

Census, 2011. Population Census of India is collection of census data reports by Govt of India. (www.census2011.co.in).

Chen, H., Teng, Y., Lu, S., Wang, Y. and Wang, J. 2015. Contamination features and health risk of soil heavy metals in China. Science of the Total Environment, 512: 143-153.

Cheng, Z., Chen, L. J., Li, H. H., Lin, J. Q., Yang, Z. B., Yang, Y. X., Xu, X. X., Xian, J. R., Shao, J. R. and Zhu, X. M. 2018. Characteristics and health risk assessment of heavy metals exposure via household dust from urban area in Chengdu, China. Science of The Total Environment, 619: 621-629.

Dehghani, S., Moore, F., Keshavarzi, B. and Beverley, A. H. 2017. Health risk implications of potentially toxic metals in street dust and surface soil of Tehran, Iran. Ecotoxicology and Environmental Safety, 136: 92-103.

Emeh, C., Igwe, O. and Onwo, E. S. 2019. Potential effect of environmental pollution on the degree of dissolution of iron and aluminium oxides in lateritic soils. Environmental Earth Sciences, 78: 256.

Ettler, V., Cihlová, M., Jarošíková, A., Mihaljevi , M., Drahota, P., K íbek, B., Van k, A., Penížek, V., Sracek, O., Klementová, M., Engel, Z., Kamona, F. and Mapani, B. 2019. Oral bioaccessibility of metal(loid)s in dust materials from mining areas of northern Namibia. Environment International, 124: 205-215.

Goldberg, S. 1989. Interaction of aluminium and iron oxides and clay mineral and their effect on soil physical properties: A review. Commun. Soil Sci. Plant. Anal., 20: 1181-1207.

Gope, M. 2016. Risk assessment of potentially toxic elements and polycyclic aromatic hydrocarbons in the street dust $(<53 \mu \mathrm{m})$ of Asansol and Durgapur, West Bengal, India. Thesis submitted to the Department of Environmental Studies, Siksha-Bhavana, Visva-Bharati, Santiniketan.

Gope, M., Masto, R. E., George, J. and Balachandran, S. 2018. Tracing source, distribution and health risk of potentially harmful elements
(PHEs) in street dust of Durgapur, India. Ecotoxicology and Environmental Safety, 154: 280-293.

Gope, M., Masto, R. E., George, J., Hoque, R. R. and Balachandran, S. 2017. Bioavailability and health risk of some potentially toxic elements $(\mathrm{Cd}, \mathrm{Cu}, \mathrm{Pb}$ and $\mathrm{Zn})$ in street dust of Asansol, India. Ecotoxicology and Environmental Safety, 138: 231-241.

Gu, Y. G. and Gao, Y. P. 2018. Bioaccessibilities and health implications of heavy metals in exposed-lawn soils from 28 urban parks in the megacity Guangzhou inferred from an in vitro physiologically-based extraction test. Ecotoxicology and Environmental Safety, 148: 747-753.

Hu, X., Zhang, Y., Ding, Z., Wang, T., Lian, H., Sun, Y. and Wu, J. 2012. Bioaccessibility and health risk of arsenic and heavy metals (Cd, $\mathrm{Co}, \mathrm{Cr}, \mathrm{Cu}, \mathrm{Ni}, \mathrm{Pb}, \mathrm{Zn}$ and $\mathrm{Mn}$ ) in TSP and PM2. 5 in Nanjing, China. Atmospheric Environment, 57: 146-152.

Hua, S., Tian, H., Wang, K., Zhu, C., Gao, J., Ma, Y., Xue, Y., Wang, Y., Duan, S. and Zhou, J. 2016. Atmospheric emission inventory of hazardous air pollutants from China's cement plants: Temporal trends, spatial variation characteristics and scenario projections. Atmospheric Environment, 128: 1-9.

Hussain, K., Rahman, M., Prakash, A. and Hoque, R. R. 2015. Street dust bound PAHs, carbon and heavy metals in Guwahati city-Seasonality, toxicity and sources. Sustainable Cities and Society, 19: 17-25.

ICMR. 2009. Nutrient requirements and recommended dietary allowances for Indians, Hyderabad (India). National Institute of Nutrition, Indian Council of Medical Research.

Iwegbue, C. M., Oliseyenum, E. C. and Martincigh, B. S. 2017. Spatiotemporal distribution of metals in household dust from rural, semi-urban and urban environments in the Niger Delta, Nigeria. Environmental Science and Pollution Research, 24: 14040-14059.

Kefeni, K. K. and Okonkwo, J. O. 2013. Trace metals, anions and polybromodiphenyl ethers in settled indoor dust and their association. Environmental Science and Pollution Research, 20: 4895-4905.

Kelepertzis, E., Argyraki, A., Botsou, F., Aidona, E., Szabó, Á. and Szabó, C. 2019. Tracking the occurrence of anthropogenic magnetic particles and potentially toxic elements (PTEs) in house dust using magnetic and geochemical analyses. Environmental Pollution, 245: 909-920.

Khillare, P. S., Balachandran, S. and Meena, B. R. 2004. Spatial and temporal variation of heavy metals in atmospheric aerosol of Delhi. Environmental Monitoring and Assessment, 90: 1-21.

Kulshrestha, A., Satsangi, P. G., Masih, J. and Taneja, A. 2009. Metal concentration of PM2.5 and PM10 particles and seasonal variations in urban and rural environment of Agra, India. Science of the Total Environment, 407: 6196-6204.

Kurt-Karakus, P. B. 2012. Determination of heavy metals in indoor dust from Istanbul, Turkey: Estimation of the health risk. Environment International, 50: 47-55.

Labar, R. and Kundu, T. K. 2018. Barrier inhomogeneities in n-ZnO/p-Si heterojunctions fabricated with $\mathrm{ZnO}$ nanorods. Journal of Electronic Materials, 47: 3628-3633.

LaGoy, P. K. 1987. Estimated soil ingestion rates for use in risk assessment. Risk Analysis, 7: 355-359.

Latif, M. T., Yong, S. M., Saad, A., Mohamad, N., Baharudin, N. H., Mokhtar, M. B. and Tahir, N. M. 2014. Composition of heavy metals in indoor dust and their possible exposure: A case study of preschool children in Malaysia. Air Quality, Atmosphere and Health, 7: 181-193.

Li, H., Qian, X., Hu, W., Wang, Y. and Gao, H. 2013. Chemical speciation and human health risk of trace metals in urban street dusts from a metropolitan city, Nanjing, SE China. Science of the Total Environment, 456: 212-221.

Li, Y., Pi, L., Hu, W., Chen, M., Luo, Y., Li, Z., Su, S., Gan, Z. and Ding, S. 2016. Concentrations and health risk assessment of metal(loid)s in indoor dust from two typical cities of China. Environmental Science and Pollution Research, 23: 9082-9092.

Liang, J., Feng, C., Zeng, G., Gao, X., Zhong, M., Li, X., Li, X., He, X. 
and Fang, Y. 2017. Spatial distribution and source identification of heavy metals in surface soils in a typical coal mine city, Lianyuan, China. Environmental Pollution, 225: 681-690.

Lin, T. S. and Shen, F. M. 2003. Trace metals in Chinese joss stick smoke. Bulletin of Environmental Contamination and Toxicology, 7: $135-141$.

Lin, T. S. and Shen, F. M. 2005. Trace metals in mosquito coil smoke. Bulletin of Environmental Contamination and Toxicology, 74: 184-189.

Lin, Y. S., Fang, F. M., Wu, J. Y., Zhu, Z., Zhang, D. and Xu, M. 2016. Heavy metal in indoor dust of Huainan, China: Concentrations, affecting factors and risk assessment. Fresenius Environ. Bull., 25: 4651-4659.

Lu, S. G., Bai, S. Q. and Xue, Q. F. 2007. Magnetic properties as indicators of heavy metals pollution in urban topsoils: a case study from the city of Luoyang, China. Geophysical Journal International, 17: 568-580.

Lu, X., Zhang, X., Li, L. Y. and Chen, H. 2014. Assessment of metals pollution and health risk in dust from nursery schools in Xi' an, China. Environmental Research, 128: 27-34.

Muhamad-Darus, F., Nasir, R. A., Sumari, S. M., Ismail, Z. S. and Omar, N. A. 2017. Nursery schools: Characterization of heavy metal content in indoor dust. Asian Journal of Environment-Behaviour Studies, 2: 63-70.

Nawazish, S., Bukhari, S. M., Muhammad, A., Khan, I. U., Alhassan, A. J., Hussain, M. and Zaidi, A. 2017. Correlation analysis of toxic metals on motorway and national highway. Kuwait Journal of Science, 44(2): 121-128.

Novo, L. A., Onishi, V. C., Bernardino, C. A. and Da Silva, E. F. 2017. Metal bioaccumulation by plants in roadside soils: Perspectives for bioindication and phytoremediation. In: Enhancing Cleanup of Environmental Pollutants, pp. 215-230.

Oomen, A. G., Hack, A., Minekus, M., Zeijdner, E., Cornelis, C., Schoeters, G., Verstraete, W., Wiele, T. V. De, Wragg, J., Rompelberg, C. J. M., Sips, A. J. A. M. and Wijnen, J. H. V. 2002. Comparison of five in vitro digestion models to study the bioaccessibility of soil contaminants. Environmental Science and Technology, 3: 3326-3334.

Pacyna, J. M., Pacyna, E. G. and Aas, W. 2009. Changes of emissions and atmospheric deposition of mercury, lead, and cadmium. Atmospheric Environment, 43: 117-127.

Pelfrene, A., Waterlot, C. and Douay, F. 2013. Influence of land use on human bioaccessibility of metals in smelter-impacted soils. Environmental Pollution, 178: 80-88.

Pelfrene, A., Waterlot, C., Mazzuca, M., Nisse, C., Cuny, D., Richard, A., Denys, S., Heyman, C., Roussel, H., Bidar, G. and Douay, F. 2012. Bioaccessibility of trace elements as affected by soil parameters in smelter-contaminated agricultural soils: A statistical modeling approach. Environmental Pollution, 160: 130-138.

Pitawala, A., Herath, D. and Piyatunga, N. 2013. Chemical characterization of household dust in two major cities: Colombo, the capital and Kandy, the hill capital, Sri Lanka. Carpathian Journal of Earth and Environmental Sciences, 8: 89-95.

Plumejeaud, S., Reis, A. P., Tassistro, V., Patinha, C., Noack, Y. and Orsière, T. 2018. Potentially harmful elements in house dust from Estarreja, Portugal: characterization and genotoxicity of the bioaccessible fraction. Environmental Geochemistry and Health, 40: 127-144.

Praveena, S. M., Abdul Mutalib, N. S. and Aris, A. Z. 2015. Determination of heavy metals in indoor dust from primary school (Sri Serdang, Malaysia): Estimation of the health risks. Environmental Forensics, 16: 257-263.

Ram, S. S., Majumder, S., Chaudhuri, P., Chanda, S., Santra, S. C., Maiti, P. K., Sudarshan, M. and Chakraborty, A. 2014. Plant canopies: Biomonitor and trap for re-suspended dust particulates contaminated with heavy metals. Mitigation and Adaptation Strategies for Global Change, 19: 499-508.
Rasmussen, P. E., Levesque, C., Chénier, M., Gardner, H. D., Jones-Otazo, H. and Petrovic, S. 2013. Canadian House Dust Study: Population-based concentrations, loads and loading rates of arsenic, cadmium, chromium, copper, nickel, lead, and zinc inside urban homes. Science of the Total Environment, 443: 520-529.

Rasmussen, P. E., Subramanian, K. S. and Jessiman, B. J. 2001. A multielement profile of house dust in relation to exterior dust and soils in the city of Ottawa, Canada. Science of the Total Environment, 267: 125-140.

Rasmussen, P.E., Levesque, C., Chenier, M. and Gardner, H.D. 2018. Contribution of metals in resuspended dust to indoor and personal inhalation exposures: Relationships between PM10 and settled dust. Building and Environment, 143: 513-522

Rohra, H., Tiwari, R., Khare, P. and Taneja, A. 2018. Indoor-outdoor association of particulate matter and bounded elemental composition within coarse, quasi-accumulation and quasi-ultrafine ranges in residential areas of northern India. Science of the Total Environment, 631-632: 1383-1397.

Roussel, H., Waterlot, C., Pelfrêne, A., Pruvot, C., Mazzuca, M. and Douay, F. 2010. Cd, $\mathrm{Pb}$ and $\mathrm{Zn}$ oral bioaccessibility of urban soils contaminated in the past by atmospheric emissions from two lead and zinc smelters. Archives of Environmental Contamination and Toxicology, 58: 945-954.

Ruby, M. V., Davis, A., Schoof, R., Eberle, S. and Sellstone, C. M. 1996. Estimation of lead and arsenic bioavailability using a physiologically based extraction test. Environmental Science and Technology, 30: 422-430.

Sen, I. S., Bizimis, M., Tripathi, S. N. and Paul, D. 2016. Lead isotopic fingerprinting of aerosols to characterize the sources of atmospheric lead in an industrial city of India. Atmospheric Environment, 129: 27-33.

Shakya, P. R. 2013. Chemical associations of lead, cadmium, chromium, nickel and zinc in household dust of Kathmandu metropolitan area. Pakistan Journal of Analytical \& Environmental Chemistry, 14: 7.

Shen, W., Liu L., Yan B., Wang J., He P., Zhou C., Huo X., Zhang W., Xu G. and Ding, Q. 2017. Cement industry of China: Driving force, environment impact and sustainable development. Renewable and Sustainable Energy Reviews, 75: 618-628.

Smith, R. L. 1994. Use of Monte Carlo simulation for human exposure assessment at a superfund site. Risk Analysis, 14: 433-439.

Soleimani, M., Amini, N., Sadeghian, B., Wang, D. and Fang, L. 2018. Heavy metals and their source identification in particulate matter (PM2.5) in Isfahan City, Iran. Journal of Environmental Sciences, 72: 166-175.

Stanek, E. J., Calabrese, E. J. and Zorn, M. 2001. Soil ingestion distributions for Monte Carlo risk assessment in children. Human and Ecological Risk Assessment, 7: 357-368.

Sulaiman, F. R., Bakri, N. I. F., Nazmi, N. and Latif, M. T. 2017. Assessment of heavy metals in indoor dust of a university in a tropical environment. Environmental Forensics, 18: 74-82.

Torres-Sánchez, R., de la Campa, A. M. S., Beltrán, M., Sánchez-Rodas, D. and Jesús, D. 2017. Geochemical anomalies of household dust in an industrialized city (Huelva, SW Spain. Science of the Total Environment, 587: 473-481.

Turner, A. 2011. Oral bioaccessibility of trace metals in household dust: A review. Environmental Geochemistry and Health, 33: 331-341.

USEP 2011. A Exposure Factors Handbook (ed.), http://cfpub.epa.gov/ncea/ risk/recordisplay.cfm? deidD236252, US Environmental Protection Agency, Washington DC, USA.

USEPA 1991. Risk Assessment Guidance for Superfund: Volume 1, Human Health Evaluation Manual, Washington, DC, USA.

Wan, D., Han, Z., Liu, D. and Yang, J. 2016. Pollution levels and spatial distribution of heavy metals in house dust from an industrial area in Xi'an, Central China. Fresenius Environ. Bull., 25: 839-851. 
Wang, K., Tian H., Hua S., Zhu C., Gao J., Xue Y., Hao J., Wang Y. and Zhou, J. 2016. A comprehensive emission inventory of multiple air pollutants from iron and steel industry in China: Temporal trends and spatial variation characteristics. Science of The Total Environment, 559:7-14.

Yang, X.G., Li, Y.P., Ma, G.S., Hu, X.Q., Wang, J.Z., Cui, Z.H., Wang, Z.H., Yu, W.T., Yang, Z.X. and Zhai, F.Y. 2005. Study on weight and height of the Chinese people and the differences between 1992 and 2002. Chinese J. Epidemiology, 26: 489-93.

Yoshinaga, J., Yamasaki, K., Yonemura, A., Ishibashi, Y., Kaido, T., Mizuno, K., Takagi, M. and Tanaka, A. 2014. Lead and other elements in house dust of Japanese residences-Source of lead and health risks due to metal exposure. Environmental Pollution, 189: 223-228. 